San Jose State University

SJSU ScholarWorks

Master's Theses

Master's Theses and Graduate Research

Fall 2011

\title{
Exploring the relationship between organizational citizenship behavior and organizational climates for creativity
}

Michael Joseph Cilla

San Jose State University

Follow this and additional works at: https://scholarworks.sjsu.edu/etd_theses

\section{Recommended Citation}

Cilla, Michael Joseph, "Exploring the relationship between organizational citizenship behavior and organizational climates for creativity" (2011). Master's Theses. 4086.

DOI: https://doi.org/10.31979/etd.hys6-nqae

https://scholarworks.sjsu.edu/etd_theses/4086

This Thesis is brought to you for free and open access by the Master's Theses and Graduate Research at SJSU ScholarWorks. It has been accepted for inclusion in Master's Theses by an authorized administrator of SJSU ScholarWorks. For more information, please contact scholarworks@sjsu.edu. 
EXPLORING THE RELATIONSHIP BETWEEN ORGANIZATIONAL CITIZENSHIP

BEHAVIOR AND ORGANIZATIONAL CLIMATES FOR CREATIVITY

\author{
A Thesis \\ Presented to \\ The Faculty of the Department of Psychology \\ San José State University \\ In Partial Fulfillment \\ of the Requirements for the Degree \\ Master of Science
}

by

Michael J. Cilla Jr.

December 2011 
(C) 2011

Michael J Cilla Jr.

ALL RIGHTS RESERVED 


\title{
EXPLORING THE RELATIONSHIP BETWEEN ORGANIZATIONAL CITIZENSHIP BEHAVIOR AND ORGANIZATIONAL CLIMATES FOR CREATIVITY
}

\author{
by
}

Michael J. Cilla Jr.

APPROVED FOR THE DEPARTMENT OF PSYCHOLOGY

SAN JOSÉ STATE UNIVERSITY

December 2011

Dr. Megumi Hosoda

Department of Psychology

Dr. Howard Tokunaga

Department of Psychology

Dr. Gregory Feist

Department of Psychology 


\begin{abstract}
EXPLORING THE RELATIONSHIP BETWEEN ORGANIZATIONAL CITIZENSHIP BEHAVIOR AND ORGANIZATIONAL CLIMATES FOR CREATVITY

by Michael J. Cilla Jr.

Technology is growing exponentially, and there is no time to waste for organizations in designing and implementing a creative climate strategy. This study was conducted to explore the relationship between organizational citizenship behaviors (OCB) and organizational climates that promote creativity. By collecting data from working undergraduate and MBA students $(N=201)$, multiple significant positive relationships were found between several of the dimensions making up both of these constructs. The results of this study show that employee perceptions of creative climates are moderately related to pro-social behaviors. For employees, working in organizations that promote a creative climate relates to having supportive social-exchange relationships and intrinsic motivation to do their jobs. Moreover, practical implications from this study suggest that organizations benefit as well. Employee perceptions of organizations with climates fostering and supporting creativity were strongly related to reports of creative output and productivity. Additionally, these perceptions were related to participants' self-reported discretionary efforts targeted toward both the organization and their fellow co-workers.
\end{abstract}




\section{ACKNOWLEDGEMENTS}

This thesis is the result of countless hours of work, which without the support of many other individuals, I would not have been able to complete. First, I need to thank my thesis advisor Dr. Megumi Hosoda for her relentless endeavors in motivating me to strive continuously for a great finished product. Her support of my topic from its very inception as an assignment in my first graduate seminar in the I-O program was also extremely important to my success.

Next, I would like to thank Dr. Marlene Turner of the University's College of Business. Having to collect my own primary data for this study seemed very daunting, and without Dr. Turner's support and assistance with connecting me to the College's research participant pool, I would not have been successful. Thanks also to Dr. Camille Johnson, for her assistance setting my study up on the College's web-portal at the perfect time to collect my data. Additional thanks go to the other College of Business faculty who provided extra credit to their students for participating in my study.

I also must thank my parents for being not only amazing parents, but also amazing friends. Without their support I would not have been able to complete my postgraduate studies in Silicon Valley, which I am forever grateful for. And of course, last and certainly not least, I would like to thank my loving wife Cherish. She was there for me from the first day until the last, and stood by my side at the brightest and roughest moments throughout this crazy ride. Without her support, I am certain that I could not have completed this long and enduring process. 


\section{TABLE OF CONTENTS}

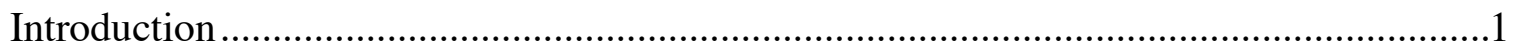

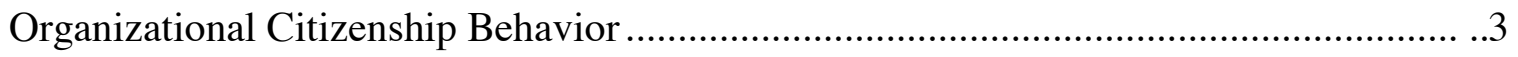

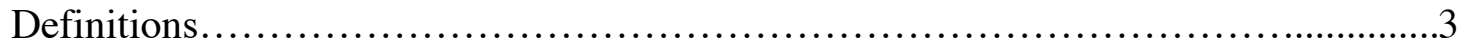

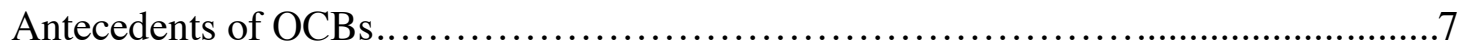

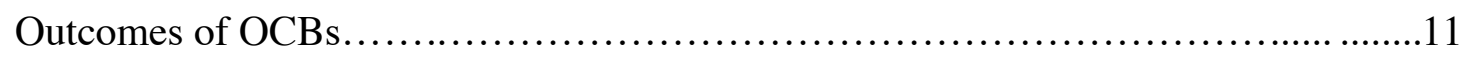

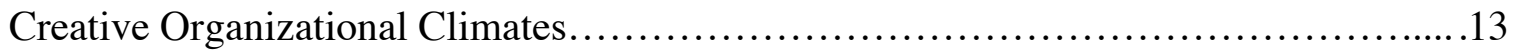

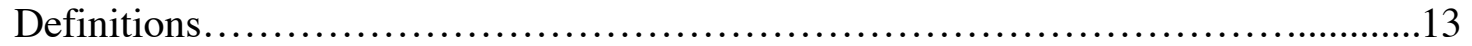

Antecedents of Creativity and Organizational Climates for Creativity ........................14

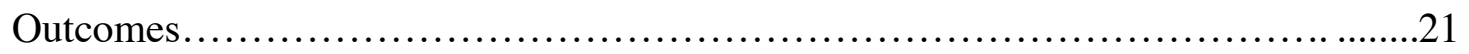

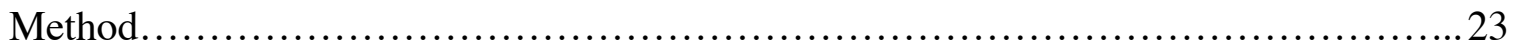

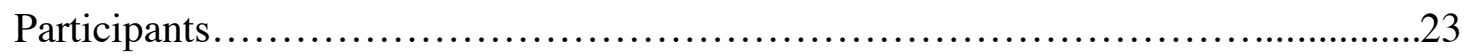

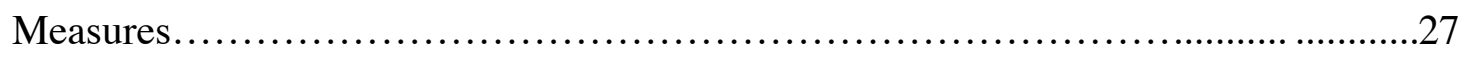

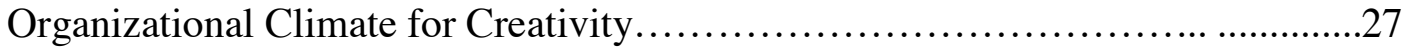

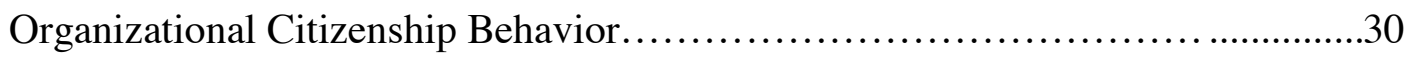

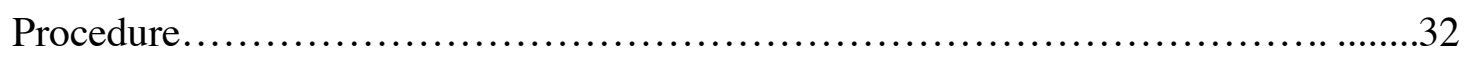

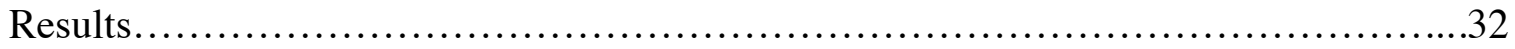

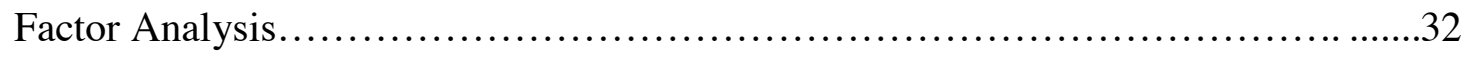

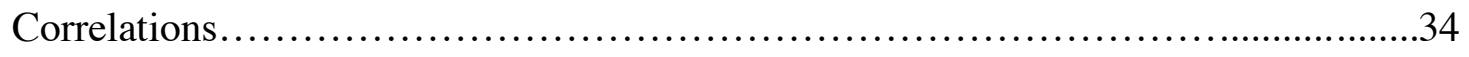

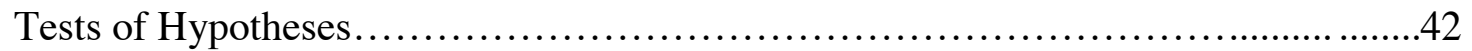

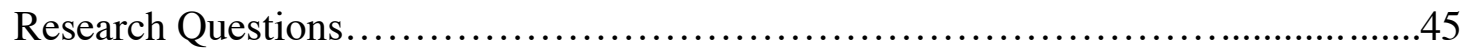

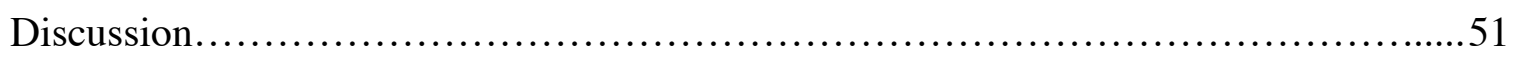

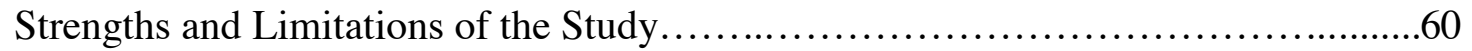

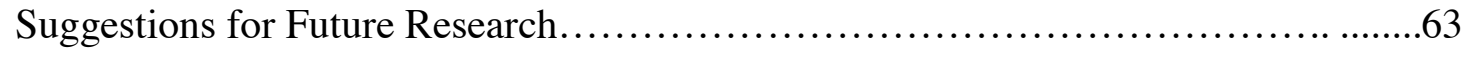

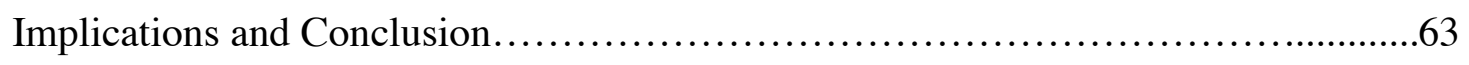

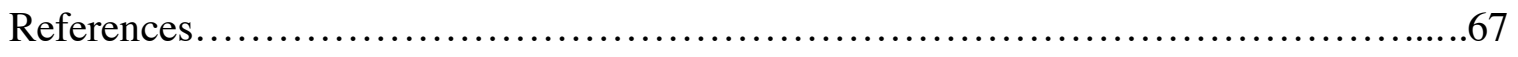




\section{LIST OF TABLES}

Table 1. Five-Factor Model of OCB Dimensions and Definitions (Organ 1988)...........5

Table 2. Dimensions of Organizational Climates for Creativity and Definitions.........16

Table 3. Demographic Information of the Sample Participants ..........................25

Table 4. Factor Loadings for KEYS Items Using Varimax Rotation.....................35

Table 5. Factor Loadings for OCB Items Using Varimax Rotation .......................39

Table 6. Means, Standard Deviations, and Correlation Matrix for KEYS and OCB .....41

Table 7. Summary of Multiple Regression Analysis for Change-oriented OCB.........42

Table 8. Summary of Multiple Regression Analysis for OCB-O....................44

Table 9. Summary of Multiple Regression Analysis for OCB-I.........................45

Table 10. Summary of Multiple Regression Analysis for Conscientiousness.............48

Table 11. Summary of Multiple Regression Analysis for Sportsmanship ................49

Table 12. Summary of Multiple Regression Analysis for Civic Virtue ...................50

Table 13. Summary of Multiple Regression Analysis for Courtesy ....................51

Table 14. Summary of Multiple Regression Analysis for Altruism.....................51 


\section{Introduction}

"A long memory and a capacity for individual recognition are well developed in man - we might therefore expect reciprocal altruism to have played an important part in human evolution" (Dawkins, 2006 p. 187). Human societies represent a large anomaly in the animal world because they are based on a detailed division of labor and cooperation between genetically unrelated individuals in large groups (Fehr \& Fischbacher, 2003). This is obviously true for modern societies with their large organizations and nation states, but it also holds for hunter-gatherers, who typically have dense networks of exchange relations and practice sophisticated forms of food sharing, cooperative hunting, and collective warfare. For researchers examining the occurrence of prosocial behavior in organizational or work environments, such discretionary behaviors, "not directly or explicitly recognized by a formal reward system, and that in the aggregate, promote the effective functioning of the organization", has been known as organizational citizenship behavior (OCB) (Organ, 1988, p. 4).

A current review of the OCB literature has identified a possible area that has yet to be addressed by researchers in the fields of organizational behavior (OB) and industrial and organizational (I-O) psychology. More specifically, based on similarities between the individual and organizational antecedent variables associated with OCB and those with an organization's climate that foster employee creativity - it indicates the possibility for a positive relationship to exist between the dimensions that comprise organizational climates for creativity and OCB. For example, social exchange variables (e.g., leadermember exchange, perceived organizational support) and attitudinal or emotional 
variables (e.g., positive affectivity, emotion, mood) are components in the theoretical models for both OCB (Podsakoff, MacKenzie, Paine, \& Bachrach, 2000) and organizational climates for creativity (Hunter, Bedell, \& Mumford, 2007), and these constructs have seldom been tested simultaneously.

A recent study by Alge, Ballinger, Tangirala, and Oakley (2006) examined a model that positioned employees' information privacy as a predictor of psychological empowerment, which led to employee extra-role performance in the form of both OCB and creativity. With this particular study though, the measures of OCB and creativity were analyzed as two separate criterion variables, but the authors did not provide a detailed interpretation for their finding on the relationship between OCB and creativity. Nonetheless, empirical testing of this model resulted in moderately strong positive relationships between co-worker ratings of employee creativity and OCB targeted at both the organization as a whole (e.g., by not complaining over trivial matters) and individuals' coworkers (e.g., altruism). Although creativity (as an outcome variable) and OCB have been directly measured (e.g., Alge et al., 2006), the specific details concerning the relationship between creative climate and OCB remain to be identified.

The current study's rationale posits a more in-depth analysis of the relationship between organizational climates for creativity and OCB. Another example of why to pose an argument for such a link is based on work by Schepers and Van Den Berg (2007). One variable they studied - employee knowledge sharing, as defined as "the tendency to provide expertise to fellow professionals" (p.413), was one of the antecedents for organizational climates that promote creativity. Although these brief 
examples suggest that the examination of how an organization's creative climate is related to OCB may be worthwhile in obtaining a better understanding of fostering and supporting both types of employee behavioral outcomes (prosocial and creative), the proceeding sections will delineate this rationale in further depth.

The following sections include a review of the literature on OCB and organizational climates for creativity: their antecedents, theoretical underpinnings, and their outcomes. In particular, the parallels of their similar antecedent variables and theoretical models are examined, following with a description of the present study that has incorporated the measurement of both constructs simultaneously, and a discussion of implications surrounding those results. The overall goal of attempting to identify such a relationship between OCB and creative organizational climates is supported by the apparent need for novel and original research within the OB and I-O psychology domains (Organ, Podsakoff, \& MacKenzie, 2006; McLean, 2005) as well as the hope to uncover beneficial knowledge for increasing organizational performance and employee cooperation in these troubling economic times (Borghini, 2005).

\section{Organizational Citizenship Behavior}

\section{Definitions}

From the time that Organ (1988) first coined the term in the 1980s, over 650 articles have been published on $\mathrm{OCB}$ and related constructs within the fields of $\mathrm{OB}$ and I-O psychology (Podsakoff, Whiting, Podsakoff, \& Blume, 2009). Organ's (1988) original definition of OCB was "individual behavior that is discretionary, not directly or explicitly recognized by the formal reward system, and that in the aggregate, promotes 
the effective functioning of the organization" (p. 4). This definition was later modified such that OCB is "performance that supports the social and psychological environment in which task performance takes place" (Organ, 1997, p. 95). Perhaps this change was due to the fact that the original definition states that citizenship behavior is voluntary, however, individuals may indeed vary in whether they see citizenship behaviors as discretionary or not (Organ et al., 2006).

This modification also entertains the possibility that OCB may not only be performed by employees at their discretion, but that they may do so while using OCB instrumentally to enhance supervisor performance evaluations of them (Hui, Law, \& Lam, 2000). More specifically, Hui et al. employed a quasi-experimental field study to examine whether OCB was related to receiving formal organizational rewards such as promotions. Results showed that both self-ratings and supervisor ratings of employee OCB were related to promotions, and that employees who perceived OCB to be instrumental to their promotions were more likely to perform OCB before receiving a promotion.

Over the years, the measurement and dimensionality of OCB have evolved from a two-factor model that included altruism and generalized compliance toward the organization (Smith, Organ, \& Near, 1983) to a five-factor model that includes altruism, generalized compliance, conscientiousness, sportsmanship, courtesy, and civic virtue (Organ, 1988) to finally a seven-factor model that further differentiates OCB into helping, sportsmanship, organizational loyalty, organizational compliance, individual 
initiatives, civic virtue, and self-development (Organ et al., 2006). Table 1 provides detailed definitions and descriptions of the five-factor model.

Table 1. Five-Factor Model of OCB Dimensions and Definitions (Organ 1988)

\begin{tabular}{ll}
\hline Dimension & Definition \\
\hline Conscientiousness & $\begin{array}{l}\text { Going well beyond the minimum requirements of the } \\
\text { organization in the areas of attendance, obeying rules and } \\
\text { regulations, and/or taking breaks. }\end{array}$ \\
Sportsmanship & $\begin{array}{l}\text { Willingness to tolerate the inevitable inconveniences and } \\
\text { impositions of work without complaining, as well as } \\
\text { maintaining a positive attitude when things do not go as one } \\
\text { plans. }\end{array}$ \\
Civic Virtue & $\begin{array}{l}\text { Macro-level interest in, or commitment to the organization as a } \\
\text { whole, displayed such as participating actively in meetings, } \\
\text { monitoring the organization's environment for potential threats, } \\
\text { and looking out for its best interests. }\end{array}$ \\
Courtesy & $\begin{array}{l}\text { Behaviors aimed at preventing work-related problems with } \\
\text { others from occurring. }\end{array}$ \\
Altruism & $\begin{array}{l}\text { Behaviors that have the effect of helping specific others with a } \\
\text { work-relevant problem. }\end{array}$ \\
\hline
\end{tabular}

Some researchers (Williams \& Anderson, 1991) have differentiated the focal target of the OCB among the dimensions, such that OCB can be defined as prosocial or helping behavior directed at other coworkers (OCB-I) (e.g., altruism and courtesy toward other individuals) or as prosocial behavior directed toward the employee's organization (OCB-O) (e.g., sportsmanship, civic virtue, and conscientiousness in promoting the welfare of the organization) (Williams \& Anderson, 1991). Regarding the dimension of OCB-O, the majority of studies (e.g., Podsakoff, et al., 2000) have been devoted to the affiliative forms of such behavior (i.e., sportsmanship, compliance, conscientiousness), 
but a further distinction has been made that attends to a form of OCB that challenges the status quo of the organization (Bettencourt, 2004).

This set of behaviors where employees challenge the status quo through suggestions for constructive changes in work methods, processes, and policies is referred to in the literature as change-oriented OCB (Choi, 2007). Behaviors such as making and voicing suggestions tend to improve work performance but are subject to disrupting social relationships because of the possible implications resulting from challenging the status quo of the workplace (LePine \& Van Dyne, 1998). In a recent study, Choi (2007) identified workplace characteristics and psychological mechanisms that reportedly lead to increases in this form of OCB. Using a longitudinal design, this study simultaneously investigated individual employee perceptions as well as group perceptions in a large Korean electronics company in order to examine how work-environment perceptions influenced change-oriented OCB. Results showed a strong vision from top management and an innovative climate were positively related to change-oriented OCB at both the individual and work-group levels.

This distinction between affiliative- and status-quo-challenging OCB is especially pertinent to the present study. Organizations are in the process of trying to maneuver through turbulent economic times and may be in need of inspiring creativity among their employees. Organizations most likely need to adopt a more creative culture or climate in the hopes of encouraging employees to display an interest in the business operations of their organizations and to be strategic in focusing on problems that may arise in the future. Thus promoting employees' individual initiative behaviors will need to become a 
consistent management philosophy (Borghini, 2005). The possible relationship between OCB and creativity is only touched upon through a discussion of change-oriented OCB. However, these behaviors might lay the theoretical foundation for a closer exploration of the prevalence of OCB in organizations that promote climates for creativity.

\section{Antecedents of OCBs}

Research examining OCB has focused on potential antecedents, including personality traits (Borman, Penner, Allen \& Motowidlo, 2001; Konovsky \& Organ, 1996; Organ \& Ryan, 1995), mood (Miles, Spector, Borman, \& Fox, 2002), employee attitudes (Bateman \& Organ, 1983; Konovsky \& Pugh, 1994; Organ \& Ryan, 1995), leader behaviors (Pillai, Schriesheim, \& Williams, 1999; Podsakoff, MacKenzie, Moorman, \& Fetter, 1990), employee perceptions of fairness (Moorman, 1991; Niehoff \& Moorman, 1993), and task characteristics (Piccolo \& Colquitt, 2006; Podsakoff, MacKenzie, \& Bommer, 1996).

Past investigations of OCB have shown that the personality trait of conscientiousness predicts higher levels of employee altruism (Konovsky \& Organ, 1996) and volunteering for extra work (Motowidlo \& Van Scotter, 1994). Individuals with high levels of conscientiousness can be characterized as having qualities such as being dependable, careful, thorough, responsible, organized, achievement oriented, and aware of the planning of their future (Mount \& Barrick, 1995). Research has also identified a positive relationship between conscientiousness and OCB as contextual performance (i.e., contributions that sustain an ethos of cooperation and interpersonal 
supportiveness of the group) (Hattrup, O'Connell, \& Wingate, 1998; LePine \& Van Dyne, 2001; Van Scotter, \& Motowidlo, 1996).

OCB can be encouraged by positive emotions as well (Isen \& Daubmen, 1984). While negative emotions may prompt avoidance tendencies for individuals to exit certain situations, positive emotions might induce approach tendencies for individuals. For example, Isen and Daubmen demonstrated that people in good moods engaged in behavior that supported their mood- thus it makes sense that people in such a positive affective state might choose to engage in altruistic behavior as a means for continuing to feel good.

Building on this rationale, Miles, Spector, Borman, and Fox (2002) tested portions of their model proposing that environmental conditions as perceived by employees relate to their emotional reactions that subsequently influence their behavior. These researchers found positive emotion to be a stronger predictor of OCB than perceived working conditions (e.g., organizational constraints, inadequate training/resources, amount of workload, and the perception of interpersonal conflict among workers). Specifically, employee perceptions of the work environment explained $11 \%$ of the variance in OCB, but when positive emotion was included in the analyses it accounted for additional 13\% of the variance in $\mathrm{OCB}$.

Similarly, organizational commitment has been studied as an antecedent to OCB (Organ \& Ryan, 1995). Affective commitment is the emotional component of organizational commitment - characterized as an employee's psychological attachment to the organization (i.e., employees stay with the company because they genuinely feel good 
from being at work) (Meyer \& Allen, 1997). It should be no surprise then that relationships have been found between affective organizational commitment and OCB consistently (e.g., Moorman, Niehoff, \& Organ, 1993; Organ \& Ryan, 1995).

Social exchange variables are defined as the contextual and situational variables which result from the interaction between the employee and a variety of other actors including the employee's supervisors, coworkers, or the employee's conceptualization of the organization as a whole entity (Konovsky \& Pugh, 1994). A social-exchange model of OCB suggests that trust in employees' supervisors' functions as a mediator of the relationship between perceptions of procedural fairness in the supervisor's decisionmaking and OCB.

Kamdar and Van Dyne (2007) demonstrated that in work settings where social exchange relationships were of high quality, the positive correlations between personality traits such as agreeableness and conscientiousness and both employee task- and contextual- performance were weaker. High quality social exchanges were defined as open-ended streams of transactions with participants both making contributions and receiving benefits, in the forms of leader-member exchange (LMX) and team-member exchange (TMX). The authors explain their findings based on trait activation theory "where interactions in which high quality social exchange relationships weaken the positive effects of personality traits on performance" (Tett \& Burnett, 2003, p.502). These findings suggest that an employee's personality may make a difference in predicting task performance and helping supervisors and co-workers when the quality of social exchange relationships is low. However, when high social exchange relationships 
are present, the amount of employee OCB will increase, regardless of their personality traits (Kamdar \& Van Dyne, 2007). For the purposes here, such empirical evidence provides reason to support the exploration of the relationship between OCB and situational variables consisting of social-relational variables, such as those associated with organizational climates that support creativity.

Other social-relational variables such as distributive, procedural, and interactional forms of justice, which deal with employee perceptions of fair outcomes, procedures, and interpersonal treatment, respectively, have accounted for increases in the variance of OCB even after controlling for attitudes such as job satisfaction (Moorman, 1991). Moorman sought to delineate the relationship between job satisfaction and OCB using analyses to control for job satisfaction dimensions that resembled the social-relational variables procedural and interactional justice. Identifying the best predictor of OCB involved using structural equation modeling (SEM) to demonstrate that interactional justice, or the manner in which supervisors treated employees as they carried out organizational policies and procedures, accounted for more of the variance in OCB than procedural and distributive justice, and more than job satisfaction too (Moorman, 1991).

Essentially, it appears that employees may be especially likely to base their decision to engage in $\mathrm{OCB}$ on the extent to which they feel they are being treated fairly by the organization. If employees feel that they are treated fairly, they may also believe that their organization values their contributions and cares about their overall well-being; better known as perceived organizational support (POS) (Podsakoff et al, 2000). POS has also been shown to predict OCB on the basis of the norm of reciprocity; employees 
perform extra-role behaviors as reciprocation to the organization from their perception of being cared for and valued by the organization (Eisenberger, Huntington, Hutchison, \& Sowa, 1986). The following section will discuss the organizational and individual outcomes associated with $\mathrm{OCB}$, and further argue for the possible benefits of the present research agenda.

\section{Outcomes of OCBs}

The relevance of OCB as an important construct in understanding prosocial organizational behavior and in implementing certain managerial practices seems to have been established thus far. However, there is still some debate as to how this phenomenon impacts organizational and individual effectiveness. A study examining the outcomes of OCB of information system (IS) implementation teams revealed that the OCB of the implementation teams created a higher level of integration climate and better project management in the organizations they serviced, which, in turn, influenced successful IS implementation (Yen, Li, \& Niehoff, 2008). This study placed an emphasis on the behavior of members of an implementation team who went above and beyond their task requirements, and whose behaviors created a climate of integration, thus engendering effective management of it. Finally, the authors have asserted that aggregated OCB did not directly influence effectiveness, but that OCB did so by indirectly promoting socioemotional support among the employees, thus facilitating the accomplishment of work.

A recent meta-analysis conducted by Podsakoff et al. (2009) demonstrated evidence for the individual benefits (e.g., managerial ratings of employee performance, reward allocation decisions, a variety of withdrawal-related criteria) and organizational benefits 
(e.g., productivity, efficiency, reduced costs, customer satisfaction, unit-level turnover) of OCB. For example, results from this meta-analysis showed that OCBs were positively related to job performance ratings, and the relationship is somewhat stronger than the relationship between task performance and job performance ratings. OCBs also had relatively strong positive relationships with reward allocation decisions and a substantial impact on reward recommendations. OCBs were negatively related to turnover intentions, actual turnover, and absenteeism. When the data were aggregated to the unitand organizational-level to identify the organizational benefits, similar results were observed. OCBs were positively related to unit-level performance and customer satisfaction, but negatively related to unit-level turnover.

Findings from this study are important for at least one reason. It provides support for a contention made by Organ (1988) that citizenship behaviors are related to organizational effectiveness in the aggregate. Additionally, the point is made by Podsakoff et al. that the homologous effects of OCBs at both the unit- and individuallevel outcomes suggest that OCB-like behavior with purposes of impression management (e.g., exhibited for reasons other than helping their coworkers or the organization) do not outweigh the generally positive effects that true $O C B s$ have on individual and organizational performance (Podsakoff et al., 2009).

Once again, a possible area for research that appears to be under-investigated is the relationship between the occurrence of OCB and organizations with climates that support and promote creativity, and if this combination results in more reported organizational creativity and productivity. A review of the literature on organizational climates for 
creativity offers some interesting antecedents paralleling both empirically and theoretically between the two constructs. Additionally, a strong argument is built in the following sections suggesting that a positive relationship might indeed exist between certain dimensions of organizational climates for creativity and those of employee OCB.

\section{Creative Organizational Climate}

\section{Definitions}

Creativity can be defined as the generation of new ideas, which leads to innovation, or the translation of these new ideas into useful new products, and creativity is commonly believed to arise as a function of an interaction between the person and the situation (Amabile, 1997; Scott \& Bruce, 1994). Although the terms creativity and innovation are not the same in the strictest sense, for the purposes here the terms will be used interchangeably. Sternberg and Lubart (1999) define creativity as "the ability to produce work that is both novel (i.e., original, unexpected) and appropriate (i.e., useful, adaptive for task constraints)" (p.3). However, innovation is about "a process of developing and implementing a new idea" (Van de Ven \& Angle, 1989, p.12).

The terms "organizational culture" and "organizational climate" appear to be used somewhat interchangeably in the literature as well (McLean, 2005). However, some authors (e.g., Amabile, Conti, Coon, \& Lazenby, 1996) make a distinction that is important when it comes to researching the phenomenon of organizational creativity and innovation. Whereas organizational culture is about deeply held assumptions, meanings, and beliefs, organizational climates are the perceptions of, or experiences in, the immediate work environment (McLean, 2005). 
It is becoming increasingly important for organizations to focus on understanding not only their own climate, but also the external climate in which they chose to operate in. In a knowledge-based economy, during these especially turbulent times, organizations face rising needs to increase not only productivity among their workers, but also their creativity (Borghini, 2005). The speed of technological change as well as globalization and increasing competition have put enormous pressure on companies to be quick to solve problems and ready to develop new ideas for products and procedures (Atwater \& Carmeli, 2009). Therefore, the goal of promoting creativity and innovation within and amongst employees is a major requirement for most organizations.

\section{Antecedents of Creativity and Organizational Climates for Creativity}

Identification of variables that might account for differences in creativity has been the topic of research and books abound in the creativity literature (Johnson, 2010). This has been the case since Guilford's (1950) address to the American Psychological Association, in which he pleaded for the systematic study of creativity within psychology. Consequently, whether or not this particular address triggered the surge in interest, the study of creativity has been approached from many different subfields of psychology such as social, organizational, personality, cognitive, clinical, and developmental ever since (Feist, 2006).

A creative person is often characterized by attributes connected with the generation of ideas, aspects of problem solving, and the drive to implement ideas (Barron \& Harrington, 1981). Numerous studies and reviews have identified personality factors related to creativity and demonstrated that creative people tend to be open to new 
experiences, unconventional, self-confident, driven, ambitious, dominant, and impulsive (Feist, 1999; Helson, 1999). However, the question at hand still remains - what situational variables exist within organizations that also promote an individual's or group's creative output?

The creativity literature offers a wide range of internal and external factors that are related to organizational innovation (Amabile, Conti, Coon, Lazenby, \& Herron 1996). Creative and innovative behaviors at work seem to be promoted by a combination of both the employees' personal creative qualities and work environment factors that promote, instead of stifle, those qualities (Mathisen \& Einarsen, 2004). Although research has identified several types of individual difference variables related to the creativity of employees, such as cognitive style (Martinsen \& Kaufmann, 1991), openness to experience (Helson, 1999), and intrinsic motivation (Amabile, 1996), it is also clear that organizations can ultimately create an atmosphere in which creativity and innovation are either fostered or stifled.

With respect to organizational climates for creativity, various dimensions have been identified in the literature (e.g., Amabile et al., 1996; McLean, 2005). Table 2 provides detailed definitions of eight key dimensions identified in the literature. Amabile et al. (1996) maintain that the social environment of creative and innovative organizations is characterized by a commitment to ambitious goals, provision of freedom and autonomy to their employees regarding the choice of tasks and how they are performed, encouragement of ideas, and sufficient time for creating ideas as well as appropriate feedback, recognition, and rewards for creative work by management. 
Table 2. Dimensions of Organizational Climates for Creativity and Definitions (Amabile, et al., 1996).

\begin{tabular}{|c|c|}
\hline Dimension & Definition \\
\hline Freedom & $\begin{array}{l}\text { Deciding what work to do or how to do it, and having a sense } \\
\text { of control over one's work. }\end{array}$ \\
\hline Challenging work & $\begin{array}{l}\text { A sense of having to work hard on challenging tasks and } \\
\text { important projects. }\end{array}$ \\
\hline $\begin{array}{l}\text { Managerial } \\
\text { encouragement }\end{array}$ & $\begin{array}{l}\text { Having a boss who serves as a good work model, sets goals } \\
\text { appropriately, supports the work group, values individual } \\
\text { contributions, and shows confidence in the work group. }\end{array}$ \\
\hline $\begin{array}{l}\text { Work-group } \\
\text { supports }\end{array}$ & $\begin{array}{l}\text { Being part of diversely skilled work groups, in which people } \\
\text { communicate well, are open to new ideas, constructively } \\
\text { challenge each other's work, trust, and help each other, and feel } \\
\text { committed to the work they are doing. }\end{array}$ \\
\hline $\begin{array}{l}\text { Organizational } \\
\text { encouragement }\end{array}$ & $\begin{array}{l}\text { Being part of an organizational culture that encourages } \\
\text { creativity through the fair, constructive judgment of ideas; } \\
\text { provides rewards and recognition for creative work, has } \\
\text { mechanisms for developing new ideas, promoting an active } \\
\text { flow of ideas, and communicates a shared vision. }\end{array}$ \\
\hline $\begin{array}{l}\text { Lack of } \\
\text { organizational } \\
\text { impediments }\end{array}$ & $\begin{array}{l}\text { Being part of an organizational culture that does not impede } \\
\text { creativity through internal political problems, harsh criticism of } \\
\text { new ideas, destructive internal competition, an avoidance of } \\
\text { risk, or an overemphasis on the status quo. }\end{array}$ \\
\hline Sufficient resources & $\begin{array}{l}\text { Having access to appropriate resources, including funds, } \\
\text { materials, facilities, and information. }\end{array}$ \\
\hline $\begin{array}{l}\text { Realistic workload } \\
\text { pressure }\end{array}$ & $\begin{array}{l}\text { The absence of extreme time pressures, unrealistic expectations } \\
\text { for productivity, and distractions from creative work. }\end{array}$ \\
\hline
\end{tabular}


Also, a review of 42 studies by Hunter, Bedell, and Mumford (2007) revealed that 14 dimensions of organizational climates for creativity produced sizeable effects with respect to measures of creativity and innovation. These dimensions include: positive peer groups, positive supervisor relations, resources, challenge, mission clarity, autonomy, positive interpersonal exchange, intellectual stimulation, top-management support, reward orientation, flexibility and risk taking, product emphasis, participation, and organizational integration.

There is also support for the importance of high-quality LMX for organizational climates for promoting employee creativity (Atwater \& Carmeli, 2009). One study examined how leaders created the impetus for creativity at work in the form of more frequent creative involvement by employees, and found that they did this through a progression of behaviors supporting high-quality interpersonal relationships (Atwater \& Carmeli, 2009). These behaviors included: raising employees' energy from serving as a role model to employees, showing openness to new ideas, planning and setting goals appropriately, supporting the work group within the organization, shaping quality communication and interaction with work-unit members, valuing individuals' contributions to the work task, showing confidence in them, and providing constructive feedback.

When leaders provided support in such a manner it subsequently led to higher levels of creative involvement at work. Further, creativity was measured as a self-report of the frequency employees involved themselves in creative work. Interestingly, this study did not examine creativity as an outcome variable, but instead as an important 
component of employees' work involvement. Results showed that employee perceptions of a supportive and high-quality relationship between themselves and their leaders were related to the energy needed for employees to engage in creative tasks and for creative involvement to emerge, especially for jobs that demanded less creativity (e.g., less complex jobs such as inventory clerk, bank teller, security officer, or production employee) (Atwaer \& Carmeli, 2009).

Social-exchange variables in relation to organizational climates for creativity have shown mixed results in the literature, however. Shalley, Gilson, and Blum (2000) surveyed 2,200 employees to examine the degree to which work environments were structured to complement the creative requirements of jobs. Proximal factors such as job characteristics (autonomy and complexity) were more strongly associated with any creative requirements of the jobs (i.e., problem solving, learning new technologies, etc.) than were distal factors such as organizational systems and procedures to support and encourage creative efforts (organizational support). However, organizational control (i.e., rules) was negatively related to any job creativity requirements. In contrast, a review of the available psychometric instruments for measuring work environments for creativity and innovation found that the combination of a supportive and challenging environment has been particularly shown to sustain high levels of creativity in individuals and teams (Mathisen \& Einarsen, 2004). Furthermore, Mathisen and Einarsen (2004) concluded that "the concept of 'support' is reflected in all [of the] instruments, and most studies reviewed demonstrated that it accurately predicts creativity or innovation in teams or organizations" (p. 135). 
However, the major factor identified in the literature that impedes creative performance is control (McLean, 2005). This could be control in decision-making, control of information flow, or perceived control in the form of reward systems that put too much emphasis on increasing extrinsic motivators. Kanter (1983) lists ten "rules for stifling innovation" that focus on control of actions, decisions, and information, the use of hierarchical structures, and a lack of supervisor support or encouragement. Accordingly, cultures that support and encourage control are likely to result in diminished creativity and innovation. The theoretical basis for this is that control negatively affects intrinsic motivation (Amabile, 1988), but expertise and creativity skills must be accompanied by intrinsic motivation to produce highly creative behavior. However, some degree of organizational formalization and centralization in key decision-making has also been shown to actually increase the organization's ability to implement innovations as well (Kimberly, 1981).

Intrinsically rewarding work may also be associated with Maslow's (1954) attainment of self-actualization, where the pursuit of higher-order, meaningful, selfdefining goals can only follow suit from meeting basic survival needs (extrinsic goals). One final contention for the parallel between the dimensions of OCB and creative organizational climates may be due to a similarity in both constructs of providing organizational environments that particularly lead employees to strive for intrinsic goal attainment at work. That is, organizational climates that promote employee creativity may be inherently conveying a message of intrinsic goals and rewards to employees, which employees may recognize as superseding their more basic needs. It may then be 
possible that employees working in these environments - believing their own basic needs for resources are met - can more actively engage in helping fellow coworkers (OCB-I). Finally, if this is possible, then these same employees might also feel the need to reciprocate to the organization for having provided the necessary resources to meet the basic needs of the employee, and thus helping the employee attain the feelings of selfactualization (OCB-O).

Based on the preceding review of the literature on both OCB and organizational climates that promote creativity, the following hypotheses are proposed for the current study:

\section{Hypothesis 1}

Participants' perceptions of organizational climates for creativity will be positively related to change-oriented OCB. This hypothesis is based on Choi's (2007) findings that innovative climates related positively to change-oriented OCB.

\section{Hypothesis 2}

Organizational climate dimensions that are associated with employee perceptions of the organization as a whole, such as freedom, challenging work, managerial encouragement, organizational encouragement, lack of organizational impediments, sufficient resources, and realistic workload pressure will be positively related to OCB-O. Hypothesis 3

Organizational climate dimensions that are associated with employee perceptions of the proximal, social-exchange factors, such as their work-group supports, will be positively related to OCB-I comparatively. 
The preceding account has established some definitions and antecedents of creativity for both the individual- and organizational-level unit of analysis. The following section covers research related to creativity as an outcome variable while also attempting to delineate a theoretical connection between organizational climates that promote creativity and the occurrence of OCB in such organizations.

\section{Outcomes}

The workplace might also be viewed as a breeding ground for new creative talent through the practice of blending ideas, and as such, employee knowledge sharing may be interpreted as one important form of prosocial behavior. Schepers and Van Den Berg (2007) presented evidence that supports a model for the social factors of workenvironment creativity (similar to climate for creativity) that demonstrates the importance of employee knowledge sharing in arriving at and reinforcing creative work outcomes. The model puts forth that employee adhocracy perceptions (e.g., learning, experimentation, risk-taking) and employee participation (i.e., freedom of expression, decision-making) allow for a creative work environment. Cooperative team perceptions (high commitment, high employee morale) and procedural justice (perception of fair management practices) lead to knowledge sharing, interaction, and communication of ideas among employees, which reinforces this environment of creativity (Schepers \& Van Den Berg, 2007). In their study of a government organization, knowledge sharing was the most important correlate of work-environment creativity, which suggests the need for promoting prosocial employee behavior in the form of knowledge sharing, especially for organizations looking to foster employee creativity as well. For the basis of the current 
topic at hand, i.e., the exploration of the relationship between OCB and organizational climates that promote creativity, these results are the strongest argument found in the literature to suggest that such a relationship exists.

Actively engaging in creative work or tasks has been theoretically linked to happiness, such that the experience of flow from being creative leads to the feelings of subjective well-being (Csikszentmihalyi, 1997; Moneta \& Csikszentmihalyi, 1996). Csikszentmihalyi defined flow as the psychological progression from beginning an activity with clear goals and receiving immediate feedback while in the act. Furthermore, the activity must involve the actor maintaining a balance between challenges and skills, a merging of action and awareness while involved, and experiencing no distractions or worries of failure. Finally, the process culminates in experiencing a complete loss of self-consciousness, having a distorted sense of time, and having such a strong appreciation for the activity that it becomes an end in itself. While it does not appear to be a large leap conceptually to presume that the positive emotional rewards and feelings of well-being from having been actively engaged in creativity may relate to one another, the following example offers empirical evidence for how mood impacts creativity.

A recent meta-analysis of 25 years of mood-creativity research provided quantifiable insight into the strength and direction of mood effects on creative performance, and to examine whether mood states influence various facets of creativity in qualitatively different ways (Baas, De Dreu, \& Nijstad, 2008). These researchers found that positive moods produced more creativity than neutral-mood controls, but there were no significant differences between negative moods and neutral-moods or between positive and negative 
moods (Baas et al., 2008). Creativity is enhanced most, then, by positive mood states that are characterized by motivation and promotion, such as the feeling of happiness.

The preceding review of literature on OCB and organizational climates for creativity clearly presents empirical examples and some theoretical arguments of the similarities in various antecedent variables and dimensional characteristics between the two. Because it remains to be examined what, if any, relationship exists between the dimensions that comprise both OCB (Podsakoff, MacKenzie, Paine, \& Bachrach, 2000) and organizational climates for creativity (Hunter, Bedell, \& Mumford, 2007), and these constructs have been seldom tested simultaneously, the following research questions are posed presently:

\section{Research Question 1}

Which dimensions of organizational climates for creativity and OCB are related?

\section{Research Question 2}

What is the relationship between the outcome variables (organizational creativity and productivity) and the dimensions of OCB?

\section{Research Question 3}

Which dimensions of organizational climates for creativity account for the most variance in the OCB dimensions?

\section{Method}

\section{Participants}

A total of 288 college students attending a large, metropolitan university in the heart of Silicon Valley in Northern California attempted to participate in the present study. 
After accounting for the one criterion that participants must have had at least six-months experience working for their current company, the study resulted in a total of 201 participants. Table 3 describes the demographic characteristics of the sample.

As can be seen from the Table 3, the majority of participants were between the ages of 18 and 25. The sample was made up of about the same number of male and female participants, with 55\% of Asian/Pacific Islander ethnicity, 27\% White, 13\% Hispanic, 2\% African American, and 3\% of some other ethnicity. The majority of the sample also reported working part-time, with more than half working one year or more in their current organization. Income ranged from under $\$ 20,000 /$ year to more than $\$ 70,000 /$ year, but most reported earning a total yearly income of under $\$ 20,000$. Approximately one-third of the sample consisted of entry-level employees, but $15 \%$ reported having managerial positions including Associate, Mid-level, and Senior-levels. The participants reported having positions in a variety of functional roles including business owners, certified trainers, coaches, interns, and military positions - with most of the participants working in organizations operating in the private/for-profit sector. Thirty-five percent of the sample reported working in organizations with fewer than 50 employees, however $18 \%$ reported working in organizations with over 10,000 employees. Organizations represented various industries, with participants sampled from aviation, banking, computer data storage, finance, retail, service, education, technology, nonprofit, and various other industries. 
Table 3. Demographic Information of the Sample Participants $(N=201)$

\begin{tabular}{lrrr}
\hline Variables & & \multicolumn{1}{c}{$\%$} \\
\hline Age & & & \\
& & & \\
& $18-25$ & 142 & 72 \\
& $26-35$ & 46 & 23 \\
& $36-55$ & 9 & 5 \\
\hline Gender & & & \\
& Female & 105 & 53 \\
& Male & 94 & 47
\end{tabular}

Ethnic

Background

Asian / Pacific Islander

$111 \quad 55$

White

$54 \quad 27$

Hispanic

African American

Other \& Mixed

$26 \quad 13$

42

63

Employment Status

Part-time

$132 \quad 66$

Full-time

$69 \quad 34$

Length of Employment

Between 6 months and $1 \quad 66 \quad 33$

year

Over 1 year

$42 \quad 21$

Over 2 years

$29 \quad 14$

Over 3 years

$27 \quad 13$

Over 4 years

$19 \quad 10$

Over 5 years

189

\section{Income}

Less than $\$ 20 \mathrm{~K}$

$115 \quad 57$

$\$ 20 \mathrm{~K}-\$ 30 \mathrm{~K}$

$19 \quad 10$

$\$ 31 \mathrm{~K}-\$ 40 \mathrm{~K}$

$20 \quad 10$

$\$ 41 \mathrm{~K}-\$ 50 \mathrm{~K}$

$\$ 51 \mathrm{~K}-\$ 60 \mathrm{~K}$

$12 \quad 6$

$\$ 61 \mathrm{~K}-\$ 70 \mathrm{~K}$

84

More than \$70K

53

$10 \quad 20$

Job Level

Entry

$\begin{array}{ll}58 & 29\end{array}$

Associate

$63 \quad 31$

Associate-level Manager

$14 \quad 7$


Table 3. Demographic Information of the Sample Participants $(N=201)$

\begin{tabular}{|c|c|c|c|}
\hline \multicolumn{4}{|l|}{ Job Level } \\
\hline Joo LeV & Mid-level & 26 & 13 \\
\hline & Mid-level Manager & 14 & 7 \\
\hline & Senior-level & 10 & 5 \\
\hline & Senior-level Manager & 3 & 1 \\
\hline & Other & 9 & 5 \\
\hline & Decline to state & 4 & 2 \\
\hline \multicolumn{4}{|l|}{ Sector } \\
\hline & Private & 109 & 54 \\
\hline & Public & 40 & 20 \\
\hline & Self Employed & 19 & 9 \\
\hline & Non Profit & 12 & 6 \\
\hline & Other & 11 & 6 \\
\hline & Decline to state & 10 & 5 \\
\hline \multicolumn{4}{|c|}{ Size of organization } \\
\hline & Below 50 employees & 70 & 35 \\
\hline & 50 - 100 employees & 25 & 12 \\
\hline & 101 - 500 employees & 24 & 12 \\
\hline & $501-1,000$ employees & 10 & 5 \\
\hline & $1,001-2,000$ employees & 11 & 5 \\
\hline & $2,001-3,000$ employees & 8 & 4 \\
\hline & $3,001-4,000$ employees & 3 & 2 \\
\hline & $4,001-5,000$ employees & 2 & 1 \\
\hline & Over 5,000 employees & 8 & 4 \\
\hline & Over 10,000 employees & & 36 \\
\hline & & & 18 \\
\hline & Decline to state & 4 & 2 \\
\hline
\end{tabular}




\section{Measures}

Organizational climate for creativity. Organizational climate for creativity was measured using the KEYS: Assessing the Climate for Creativity scale (to be referred to KEYS from hereafter) (Amabile et al., 1996). The KEYS scale focuses on employee work environment perceptions that influence the creativity of organizations on several levels, and includes various components. The instrument consists of 78 items and uses four-point response scales $(1=$ never or almost never, $2=$ sometimes, $3=$ often, and $4=$ always or almost always). The KEYS scale not only assesses eight dimensions of organizational climate (i.e., freedom, challenging work, managerial encouragement, work group supports, organizational encouragement, lack of organizational impediments, resources, work pressure), but also perceptions of organizational creativity and productivity. Mathisen and Einarsen (2004), conducting a review of the existing creative organizational climate instruments, concluded that the KEYS and one other scale intended to assess work environments conducive to creativity were well enough documented in the literature, and of acceptable psychometrically sound quality, as compared to the other instruments. Items associated with each KEYS dimension are listed below.

Freedom. Freedom was measured with four items. Sample items include "I have the freedom to decide how I am going to carry out my projects" and "I feel little pressure to meet someone else's specifications in how I do my work." Higher scores on this dimension equate with employee perceptions of more freedom in their work $(\alpha=.78)$. 
Challenging work. Challenging work was measured with five items. Sample items include "I feel that I am working on important projects" and "The organization has an urgent need for successful completion of the work I am now doing." Higher scores on this dimension equate with employees' reporting experiencing plenty of extra challenges in their work $(\alpha=.86)$.

Managerial encouragement. Managerial encouragement was measured with 11 items. Sample items include "My boss communicates well with our work group" and "My boss supports my work group within the organization." Higher scores on this dimension equate with increased levels of perceived encouragement from one's direct managers $(\alpha=.95)$.

Work group supports. Work group supports was measured with eight items. Sample items include "My co-workers and I make a good team" and "Within my work group, we challenge each other's ideas in a constructive way." Higher scores on this dimension equate with employee perception of higher quality teams with healthy work group relationships $(\alpha=.92)$.

Organizational encouragement. Organizational encouragement was measured with 15 items. Sample items include "People are encouraged to solve problems creatively in this organization" and "New ideas are encouraged in this organization." Higher scores on this dimension equate with employee perceptions of a stronger organizational vision and mission toward creativity and innovation $(\alpha=.78)$.

Lack of organizational impediments. Lack of organizational impediments was measured with 12 items. Sample items include "There are political problems in this 
organization" and "There is destructive competition within this organization." After reverse-scoring the items, higher scores on this dimension equate with employee perceptions of a healthier organizational culture free of creative roadblocks $(\alpha=.85)$.

Sufficient resources. Sufficient resources was measured with six items. Sample items include "The facilities I need for my work are readily available to me" and "I can get all the data I need to carry out my projects successfully." Higher scores on this dimension equate with employee perceptions of organizational support in the form of having the necessary resources to be creative at work $(\alpha=.92)$.

Realistic workload pressure. Realistic workload pressure was measured with five items. Sample items include "I have too much work to do in too little time" and "There are unrealistic expectations for what people can achieve in this organization." After reverse-scoring the items, higher scores on this dimension equate with employee perceptions of more organizational support in the form of having the necessary time to dedicate toward completing their work $(\alpha=.85)$.

Creativity. Creativity is one of the KEYS outcome variables, and it was measured with six items. Sample items include "My area of this organization is innovative" and "A great deal of creativity is called for in my daily work." Higher scores on this dimension equate with higher employee perceptions of individual and organizational creativity $(\alpha=$ $.93)$.

Productivity. Productivity is another KEYS outcome variable, and it was measured with six items. Sample items include "My area of this organization is effective" and 
"Overall, this organization is effective." Higher scores on this dimension equate with higher employee perceptions of individual and organizational productivity ( $\alpha=.91$ ).

Organizational citizenship behavior. OCB was assessed using the Podsakoff et al.'s (1990) 24-item measure that has reliably shown a five-factor model of OCB including conscientiousness, sportsmanship, civic virtue, courtesy, and altruism. These OCB items were all reworded from the original third-person format used to obtain supervisor ratings to a first-person format suitable for the self-report methodology used presently. Responses are anchored on a seven-point Likert format that ranges from 1 (strongly disagree) to 7 (strongly agree).

Conscientiousness. Conscientiousness was measured with five items. Sample items include "I am one of the most conscientious employees" and "I believe in giving an honest day's work for an honest day's pay." Higher scores on this dimension equate with higher self-reported conscientiousness behaviors $(\alpha=.82)$.

Sportsmanship. Sportsmanship was measured with five items. Sample items include "I consume a lot of time complaining about trivial matters" and "I have been called the "squeaky wheel" that always needs greasing". After reverse-scoring the items, higher scores on this dimension indicate more self-reported sportsmanship behavior $(\alpha=$ $.77)$.

Civic virtue. Civic virtue was measured with four items. Sample items include "I attend meetings that are not mandatory, but considered important" and "I attend functions that are not required, but help the company image" $(\alpha=.72)$. Higher scores on this dimension indicate employee behaviors that demonstrate commitment to the organization 
as a whole, displayed such as participating actively in meetings, monitoring the organization's environment for potential threats, and looking out for its best interests.

Courtesy. Courtesy was measured with five items. Sample items include "I take steps to try to prevent problems with other workers" and "I try to avoid creating problems for coworkers" $(\alpha=.82)$. Higher scores on this dimension demonstrate voluntarily helping others with, or preventing the occurrence of work-related problems.

Altruism. Altruism was measured with five items. Sample items include "I help others who have heavy workloads" and "I willingly help others who have work related problems" $(\alpha=.86)$. Higher scores on this dimension equate with overall voluntary helping of co-workers.

Change-oriented $\boldsymbol{O C B}$. Change-oriented OCB was measured using four items from Choi’s (2007) scale. Sample items include: "I frequently come up with new ideas or new work methods to perform my task," and "I often suggest work improvement ideas to others". Higher scores on this dimension equate with higher self-reported employee behaviors that challenge the status-quo in order to improve individual productivity or organizational work flow $(\alpha=.79)$.

Additionally, using this scale, OCB can also be assessed by the target the behavior is directed at; either the organization or individuals. Combining the conscientiousness, sportsmanship, and civic virtue dimensions created OCB-O as a separate dimension, and using the courtesy and altruism items created OCB-I. 


\section{Procedure}

Participants completed the OCB and Climate for Creativity scales, as well as the demographic questions as a single survey online, via the Qualtrics software application. Students were granted credit for their participation in a department-wide research subject pool in the College of Business by logging into a web-based portal and completing an online survey. Additionally, students were recruited from three sections of upper-level, undergraduate business courses, and two sections of graduate-level, MBA courses.

A necessary condition for participating in this research was that the students met a pre-screening filter for full- or part-time employment, with a minimum of six continuous months at their current employers/organizations. The survey was configured to screen participants accordingly by redirecting those who reported having less than six months tenure in their organizations to move passed the non-demographic items (i.e., organizational climates for creativity and OCB). Informed consent to participate was obtained electronically on the first screen following the introduction and instructions, and the survey concluded with a "Thank You" message on the last screen explaining the broad details and research questions for the study.

\section{Results}

\section{Factor Analysis}

Before analyzing the data with Pearson correlations and regression analyses to test the hypotheses and research questions, an evaluation of the KEYS and OCB scales' dimensionality and reliability was performed. To confirm the dimensionality of the two scales I used a principal components analysis with varimax rotation (Tabachnick \& 
Fidell, 2007). For the KEYS scale the initial factor solution resulted in 15 factors with eigenvalues greater than 1 . This solution accounted for $75 \%$ of the variance, and included five additional factors than the proposed factor structure. Another principal components analysis was conducted which calculated the extraction of ten factors, and the factor analysis accounted for $68 \%$ of the variance with all of the 78 items loading strongly to the proposed factor structure. Table 4 presents the results of this factor analysis.

Next I evaluated the factor structure of the OCB scale with the 4-item changeoriented OCB scale included. The initial factor solution extracted six factors accounting for $64 \%$ of the variance with all of the 28 items loading strongly to the proposed dimensionality of the five-dimension OCB scale and the separate change-oriented OCB scale. Table 5 presents the results of this factor analysis. Additionally, I used the same calculated extraction for the 24 items from the five-dimension OCB scale into two factors using a principal components analysis with varimax rotation to assess the fit for the proposed dimensionality of the items separating into two dimensions of OCB-I and OCBO. These two factors accounted for $43 \%$ of the variance, however, almost all of the items loaded onto the first extracted factor, with only the five items representing sportsmanship loading strongly onto the second factor. One possible explanation for this is that all of the items for that dimension are negatively worded. Table 5 presents the results of this factor analysis. 


\section{Correlations}

Table 6 describes the means, standard deviations, and correlations of the climate for creativity dimensions and OCB. As can be seen from the table, participants generally perceived their organizations' climates as geared toward promoting creativity somewhat. The dimensions of work group supports and sufficient resources displayed the highest means $(M=2.99, \mathrm{SD}=.65 ; M=2.96, \mathrm{SD}=.72$ respectively $)$. Furthermore, the participants generally self-reported high levels of OCB, with the highest mean for courtesy $(M=6.02, \mathrm{SD}=.91)$.

With a few exceptions the majority of the dimensions for both constructs displayed significant intercorrelations. For the climate for creativity scales, the dimension of managerial encouragement was strongly related to the dimensions of organizational encouragement $(r=.70, p<.01)$, sufficient resources $(r=.58, p<.01)$, and work group supports $(r=.56, p<.01)$. Organizational encouragement was also strongly related to challenging work $(r=.55, p>.01)$ and work group supports $(r=.64, p<.01)$. For the outcome dimensions, creativity was strongly related to challenging work $(r=.60, p<$ $.01)$ and organizational encouragement $(r=.60, p<.01)$. Productivity was strongly related to organizational encouragement $(r=.60, p<.01)$, sufficient resources $(r=.57, p$ $<.01)$, and managerial encouragement $(r=.55, p<.01)$.

Interestingly, a closer look at the intercorrelations of each of the climate for creativity subscales with the outcome variables of creativity and productivity shows generally stronger relationships between these subscales and productivity compared to the relationships between these subscales and creativity. 
Table 4. Factor Loadings for KEYS Items Using Varimax

Rotation

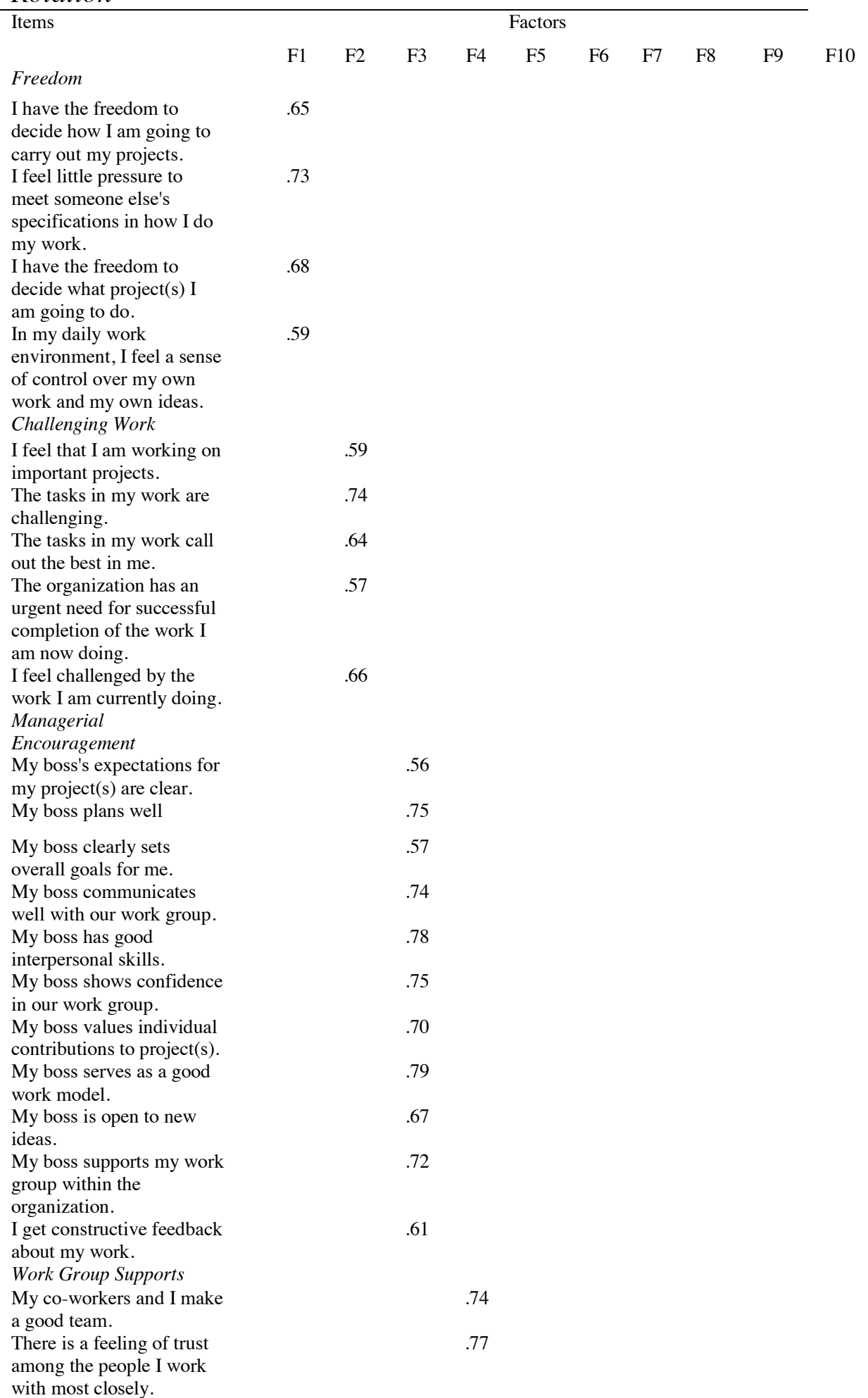


Items

Factors

$\begin{array}{llllllllll}\text { F1 } & \text { F2 } & \text { F3 } & \text { F4 } & \text { F5 } & \text { F6 } & \text { F7 } & \text { F8 } & \text { F9 } & \text { F10 }\end{array}$

People in my work group

are open to new ideas.

In my work group, people

are willing to help each

other.

There is a good blend of

skills in my work group.

The people in my work

group are committed to

our work.

There is free and open

communication within my

work group

Organizational

Encouragement

People are encouraged to

solve problems creatively

in this organization

New ideas are encouraged

in this organization.

This organization has a

good mechanism for

encouraging and

developing creative ideas.

People are encouraged to

take risks in this

organization.

In this organization, top

management expects that

people will do creative

work.

I feel that top management

is enthusiastic about my

project(s).

Ideas are judged fairly in

this organization.

People in this organization

can express unusual ideas

without the fear of being

called stupid.

Failure is acceptable in

this organization, if the

effort on the project was

good.

Performance evaluation in

this organization is fair.

People are recognized for

creative work in this

organization.

People are rewarded for

creative work in this

organization.

There is an open

atmosphere in this

organization.

In this organization, there

is a lively and active flow

of ideas.

Overall, the people in this organization have a shared vision of where we are going and trying to do. 
Items

Factors
$\begin{array}{lllll}\text { F1 } & \text { F2 } & \text { F3 } & \text { F4 } & \text { F5 }\end{array}$
F6
F7 F8
F9 F10

Lack of Organizational

Impediments

There are political

problems in this

organization.

There is destructive

competition within this

organization.

People in this organization

are very concerned about

protecting their territory.

Other areas of the

organization hinder my

project(s).

People are critical of new

ideas in this organization.

Destructive criticism is a

problem in this

organization.

People are concerned

about negative criticism of

their work in this

organization.

People in this organization

do feel pressure to produce

anything acceptable, even

if quality is lacking.

Top management is not

willing to take risks in this organization.

There is a lot of emphasis

in this organization on

doing things the way we

have always done them.

Procedures and structures

are formal in this

organization.

This organization is

strictly controlled by

upper-management.

Sufficient Resources

The facilities I need for my

work are readily available

to me.

Generally, I can get the

resources I need for my

work.

The budget for my

project(s) is generally

adequate.

I can get all the data I need

successfully.

I am able to easily get the materials I need to do my work.

The information I need for my work is easily

obtainable. 


\section{$\begin{array}{llllllllll}\text { F1 } & \text { F2 } & \text { F3 } & \text { F4 } & \text { F5 } & \text { F6 } & \text { F7 } & \text { F8 } & \text { F9 } & \text { F10 }\end{array}$}

Realistic Workload

Pressure

I have too much work to

do in too little time.

I do not have sufficient

time to do my project(s)

There are too many

distractions from project

work in this organization.

There are unrealistic

expectations for what

people can achieve in this

organization.

I feel a sense of time

pressure in my work.

Creativity

My area of this

organization is innovative.

My area of this

organization is creative.

Overall, my current work

environment is conducive

to my own creativity.

A great deal of creativity is

called for in my daily

work.

Overall, my current work

environment is conducive

to the creativity of my

work group.

I believe that I am

currently very creative in

my work.

Productivity

Overall, this organization

is effective.

My area of this

organization is productive.

My area of this

organization is effective.

Overall, this organization

is productive.

Overall, this organization

is efficient.

My area of this

organization is efficient. 
Table 5. Factor Loadings for OCB Items Using Varimax Rotation

\begin{tabular}{|c|c|c|c|c|c|c|c|c|}
\hline \multirow[t]{2}{*}{ Items } & \multicolumn{6}{|c|}{ Factors } & \multicolumn{2}{|c|}{ OCB-I / OCB-O } \\
\hline & F1 & F2 & F3 & F4 & F5 & F6 & F1 & $\mathrm{F} 2$ \\
\hline Conscientiousness & & & & & & & & \\
\hline $\begin{array}{l}\text { My attendance at work is above } \\
\text { the norm. }\end{array}$ & .63 & & & & & & 46 & \\
\hline I do not take extra breaks. & .75 & & & & & & .51 & \\
\hline $\begin{array}{l}\text { I obey company rules and } \\
\text { regulations even when no one is } \\
\text { watching. }\end{array}$ & .78 & & & & & & .64 & \\
\hline $\begin{array}{l}\text { I am one of the most } \\
\text { conscientious employees. }\end{array}$ & .76 & & & & & & .63 & \\
\hline $\begin{array}{l}\text { I believe in giving an honest } \\
\text { day's work for an honest day's } \\
\text { pay. }\end{array}$ & .65 & & & & & & .75 & \\
\hline Sportsmanship & & & & & & & & \\
\hline $\begin{array}{l}\text { I consume a lot of time } \\
\text { complaining about trivial } \\
\text { matters }(\mathrm{R}) \text {. }\end{array}$ & & .72 & & & & & & .75 \\
\hline $\begin{array}{l}\text { I tend to focus on "what's } \\
\text { wrong" rather than the positive } \\
\text { side of a situation (R). }\end{array}$ & & .78 & & & & & & .77 \\
\hline $\begin{array}{l}\text { I have a tendency to make } \\
\text { mountains out of molehills (R). }\end{array}$ & & .73 & & & & & & .70 \\
\hline $\begin{array}{l}\text { I always find fault with what my } \\
\text { organization is doing }(\mathrm{R}) \text {. }\end{array}$ & & .75 & & & & & & .72 \\
\hline $\begin{array}{l}\text { I have been called the "squeaky } \\
\text { wheel" that always needs } \\
\text { greasing (R). }\end{array}$ & & .61 & & & & & & .56 \\
\hline $\begin{array}{l}\text { I attend meetings that are not } \\
\text { mandatory, but considered } \\
\text { important. }\end{array}$ & & & .75 & & & & .48 & \\
\hline $\begin{array}{l}\text { I attend functions that are not } \\
\text { required, but help the company } \\
\text { image. }\end{array}$ & & & .81 & & & & .41 & \\
\hline $\begin{array}{l}\text { I keep abreast of changes within } \\
\text { the organization. }\end{array}$ & & & .58 & & & & .51 & \\
\hline $\begin{array}{l}\text { I read and keep up with } \\
\text { organization announcements, } \\
\text { memos, etc. } \\
\text { Courtesy }\end{array}$ & & & .53 & & & & .45 & \\
\hline $\begin{array}{l}\text { I take steps to try to prevent } \\
\text { problems with other workers. }\end{array}$ & & & & .70 & & & .71 & \\
\hline $\begin{array}{l}\text { I'm mindful of how my } \\
\text { behavior affects other people's } \\
\text { jobs. }\end{array}$ & & & & .70 & & & .80 & \\
\hline $\begin{array}{l}\text { I don't abuse the rights of } \\
\text { others. }\end{array}$ & & & & .71 & & & .79 & \\
\hline $\begin{array}{l}\text { I try to avoid creating problems } \\
\text { for coworkers. }\end{array}$ & & & & .74 & & & .68 & \\
\hline $\begin{array}{l}\text { I consider the impact of my } \\
\text { actions on coworkers. } \\
\text { Altruism }\end{array}$ & & & & .56 & & & .66 & \\
\hline $\begin{array}{l}\text { I help others who have been } \\
\text { absent. }\end{array}$ & & & & & .66 & & .63 & \\
\hline $\begin{array}{l}\text { I help others who have heavy } \\
\text { workloads. }\end{array}$ & & & & & .73 & & .62 & \\
\hline $\begin{array}{l}\text { I help orient new people even } \\
\text { though it's not required. }\end{array}$ & & & & & .72 & & .62 & \\
\hline $\begin{array}{l}\text { I willingly help others who have } \\
\text { work related problems. }\end{array}$ & & & & & .57 & & .66 & \\
\hline $\begin{array}{l}\text { I'm always ready to lend a } \\
\text { helping hand to those around } \\
\text { me. }\end{array}$ & & & & & .67 & & .69 & \\
\hline
\end{tabular}


Items
F1 F2
Factors

F4
F5
F6

.72

Change-oriented $O C B$

I frequently come up with new

ideas or new work methods to

perform my task.

I often suggest work

improvement ideas to others.

I often suggest changes to

unproductive rules or policies.

I often change the way I work to

improve efficiency.
80

.79 
Table 6. Means, Standard Deviations, and Correlation Matrix for KEYS and OCB Dimensions

\begin{tabular}{|c|c|c|c|c|c|c|c|c|c|c|c|c|c|c|c|c|c|}
\hline Variable Name & $M$ & SD & 1 & 2 & 3 & 4 & 5 & 6 & 7 & 8 & 9 & 10 & 11 & 12 & 13 & 14 & 15 \\
\hline 1. Freedom & 2.49 & .71 & ----- & & & & & & & & & & & & & & \\
\hline $\begin{array}{l}\text { 2. Challenging } \\
\text { Work }\end{array}$ & 2.43 & .73 & $.39^{* *}$ & ----- & & & & & & & & & & & & & \\
\hline $\begin{array}{l}\text { 3. Managerial } \\
\text { Encouragement }\end{array}$ & 2.79 & .79 & $.29^{*}$ & $.42^{* *}$ & ----- & & & & & & & & & & & & \\
\hline $\begin{array}{l}\text { 4. Work Group } \\
\text { Supports }\end{array}$ & 2.99 & .65 & $.33^{* *}$ & $.40^{* * *}$ & $.56^{* *}$ & ----- & & & & & & & & & & & \\
\hline $\begin{array}{l}\text { 5. Organizational } \\
\text { Encouragement }\end{array}$ & 2.52 & .73 & $.46^{* *}$ & $.55^{* *}$ & $.70^{* *}$ & $.64^{* *}$ & ----- & & & & & & & & & & \\
\hline $\begin{array}{l}\text { 6. Lack of } \\
\text { Organizational } \\
\text { Impediments }\end{array}$ & 2.81 & .56 & $.24^{* *}$ & .08 & $.19^{* *}$ & $.16^{*}$ & $.24^{* *}$ & ----- & & & & & & & & & \\
\hline $\begin{array}{l}\text { 7. Sufficient } \\
\text { Resources }\end{array}$ & 2.96 & .72 & $.29^{* *}$ & $.28^{* *}$ & $.58^{* *}$ & $.46^{* *}$ & $.55^{* *}$ & $.16^{*}$ & ----- & & & & & & & & \\
\hline $\begin{array}{l}\text { 8. Realistic Work } \\
\text { Load Pressure }\end{array}$ & 2.86 & .70 & $.16^{*}$ & -.12 & $.29^{* *}$ & .11 & $.19^{* *}$ & $.48^{* *}$ & $.31^{* *}$ & ----- & & & & & & & \\
\hline 9. Creativity & 2.14 & .77 & $.43^{* *}$ & $.60^{* *}$ & $.43^{* *}$ & $.42^{* *}$ & $.60^{* *}$ & .09 & $.24^{*}$ & .01 & ----- & & & & & & \\
\hline 10. Productivity & 2.89 & .61 & $.32^{* *}$ & $.46^{* *}$ & $.55^{* *}$ & $.51^{*}$ & $.60^{* *}$ & $.21^{* *}$ & $.57^{* *}$ & .09 & $.38^{* *}$ & ----- & & & & & \\
\hline 11. Conscientious & 5.67 & 1.12 & -.07 & .06 & -.03 & .08 & -.09 & -.04 & .00 & $-.17^{*}$ & -.03 & $.16^{*}$ & ----- & & & & \\
\hline 12. Sportsmanship & 5.17 & 1.12 & $.17^{*}$ & $.17^{*}$ & $.33^{* *}$ & $.27^{* *}$ & $.23^{* *}$ & $.23^{* *}$ & $.25^{*}$ & $.30^{* *}$ & $.14^{*}$ & $.27^{* *}$ & .06 & ---- & & & \\
\hline 13. Civic Virtue & 4.95 & 1.08 & .02 & $.23^{*}$ & $.15^{*}$ & .12 & $.14^{*}$ & .03 & .14 & -.11 & $.16^{*}$ & $.25^{* *}$ & $.35^{* *}$ & .07 & ----- & & \\
\hline 14. Courtesy & 6.02 & .91 & .09 & .09 & .11 & $.20^{* * *}$ & .01 & .13 & $.15^{*}$ & .01 & -.01 & $.21^{* *}$ & $.60^{* * *}$ & .13 & $.44^{* *}$ & ----- & \\
\hline 15. Altruism & 5.84 & .89 & .09 & $.16^{*}$ & $.16^{*}$ & $.23^{* *}$ & .07 & .10 & $.24^{* *}$ & .07 & .07 & $.24^{* *}$ & $.39^{* *}$ & $.18^{*}$ & $.41^{* *}$ & $.62^{* *}$ & ----- \\
\hline $\begin{array}{l}\text { 16. Change- } \\
\text { oriented }\end{array}$ & 5.16 & .99 & $.21^{* *}$ & $.26^{* *}$ & .03 & $.18^{*}$ & .03 & -.02 & .10 & -.07 & $.29^{* *}$ & $.20^{* *}$ & $.29^{* *}$ & .03 & $.37^{* *}$ & $.36^{* *}$ & $.53^{* *}$ \\
\hline
\end{tabular}

Correlation is significant at the .01 level. " - Correlation is significant at the .05 level. $\mathrm{N}=201$ Listwise. 
The OCB scales also displayed significant intercorrelations, with few exceptions. Conscientiousness was strongly related to courtesy $(r=.60, p<.01)$. Courtesy was strongly related to altruism $(r=.62, p<.01)$. Change-oriented OCB was strongly related to altruism $(r=.53, p<.01)$. Finally Civic virtue was moderately related to courtesy $(r=$ $.44, p<.01)$ and altruism $(r=.41, p<.01)$.

\section{Tests of Hypotheses}

Hypothesis 1 stated that all of the dimensions of organizational climates for creativity would be significantly related to change-oriented OCB. The hypothesis was tested using a multiple regression analysis with change-oriented $\mathrm{OCB}$ as a criterion variable and the eight climate dimensions as predictor variables. Twelve percent of the variance of change-oriented OCB behaviors were accounted for by the climate for creativity dimensions, $R^{2}=.12, F(8,198)=3.45, p<.01$. Among the eight dimensions, freedom $(\beta=.16, p<.05)$, challenging work $(\beta=.25, p<.01)$, and work group supports $(\beta=.18$, $p<.05$ ) were significantly related to change-oriented OCB (see Table 7).

Table 7. Summary of Multiple Regression Analysis for Change-oriented OCB

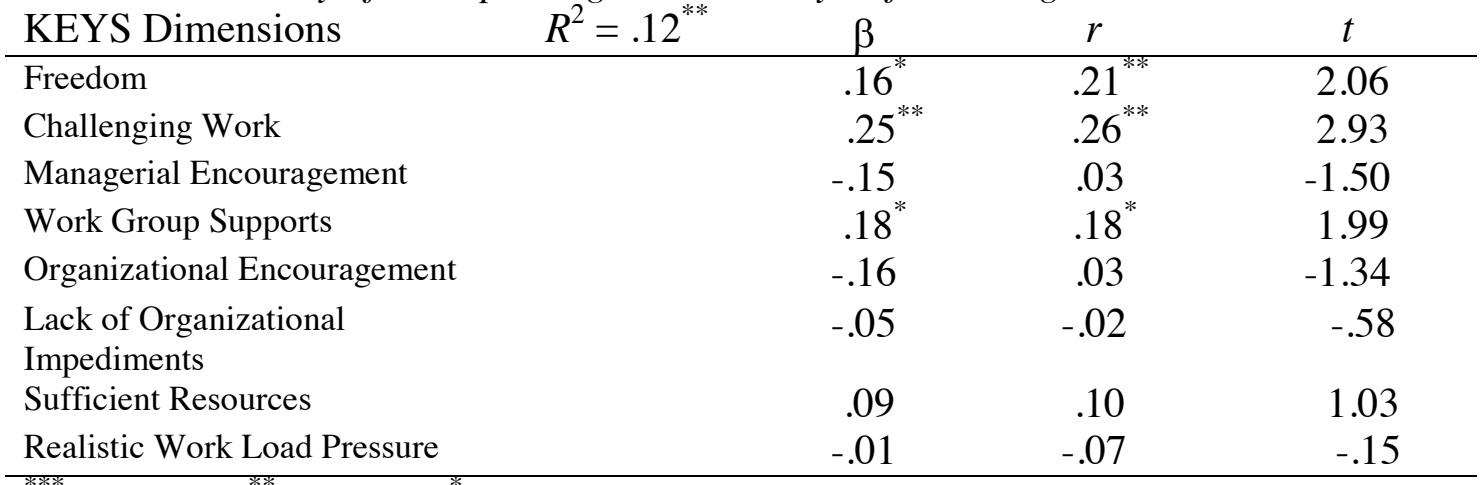

**** $-p<.001,{ }^{* *}-p<.01,,^{*}-p<.05$ 
These results show that Hypothesis 1 was partially supported, as three of the eight dimensions displayed significant beta weights. The results show that the more employees perceived having the freedom to decide how or what to do with their work, the more they believed their work is challenging and important, and the more they felt that their socialexchange work environment was healthy, the more they initiated change-oriented OCB behaviors, such as coming up with new ideas for work methods and/or suggesting changes to unproductive policies or procedures. This demonstrates how important it is for organizational leaders to ensure several factors in facilitating change-oriented OCB.

Hypothesis 2 stated that the climate for creativity dimensions of freedom, challenging work, managerial encouragement, organizational encouragement, lack of organizational impediments, sufficient resources, and realistic workload pressure would be positively related to OCB-O. As mentioned earlier, the result of the factor analysis did not conform with the proposed structure, such that only one of the three proposed OCB-O dimensions (i.e., sportsmanship) loaded onto a separate factor, however I still decided to test two hypotheses regarding the dimensions of OCB-O and OCB-I.

To test this hypothesis, a multiple regression analysis was performed with OCB-O as a criterion variable and the eight climate dimensions as predictor variables. This resulted in $12 \%$ of the variance of OCB-O behaviors being accounted for by the climate for creativity dimensions, $R^{2}=.12, F(8,198)=1.62, p<.01$. Challenging work $(\beta=.19, p$ $<.05)$, work group supports $(\beta=.18, p<.05)$, and organizational encouragement $(\beta=-$ $.26, p<.05$ ) all displayed significantly unique relationships with OCB-O (see Table 8). 
Table 8. Summary of Multiple Regression Analysis for OCB-O

\begin{tabular}{|c|c|c|c|c|}
\hline KEYS Dimensions & $\begin{array}{l}R^{2}= \\
.12^{* *}\end{array}$ & $\beta$ & $r$ & $t$ \\
\hline Freedom & & -.05 & .06 & -.70 \\
\hline Challenging Work & & $.19^{*}$ & $.23^{* *}$ & 2.25 \\
\hline Managerial Encouragement & & .17 & $.23^{* *}$ & 1.66 \\
\hline Work Group Supports & & $.18^{*}$ & $.24^{* *}$ & 2.01 \\
\hline $\begin{array}{l}\text { Organizational } \\
\text { Encouragement }\end{array}$ & & $-.26^{*}$ & $.14^{*}$ & -2.19 \\
\hline $\begin{array}{l}\text { Lack of Organizational } \\
\text { Impediments }\end{array}$ & & -.12 & .11 & -1.54 \\
\hline Sufficient Resources & & .11 & $.19^{* *}$ & 1.30 \\
\hline $\begin{array}{l}\text { Realistic Work Load } \\
\text { Pressure }\end{array}$ & & .07 & .01 & .82 \\
\hline
\end{tabular}

$-p<.001, "-p<.01, "-p<.05$

These results partially support Hypothesis 2, suggesting that when employees perceive a sense of having to work hard on challenging tasks and important projects, while having the support of skilled and constructive teams, they are more likely to engage in pro-organizational behaviors to some extent. However, this result is also somewhat counterintuitive in that less organizational encouragement leads to higher reports of OCB-O. This result is also further touched upon later.

Hypothesis 3 stated that the KEYS dimensions of managerial encouragement and work groups supports would be positively related to OCB-I. To test this hypothesis I performed a multiple regression analysis with OCB-I as the criterion variable and the eight climate dimensions as predictor variables. Results show that $14 \%$ of the variance of OCB-I behaviors were accounted for by the dimensions of climate for creativity, $R^{2}=.14$, $F(8,198)=4.16, p<.001$. Work group supports $(\beta=.29, p=.001)$, organizational encouragement $(\beta=-.43, p<.001)$, and sufficient resources $(\beta=.22, p=.01)$ displayed significant beta weights for the relationships between these dimensions (see Table 9). 
These results partially support Hypothesis 3 , as only one of the predicted climate for creativity dimensions (i.e., work group supports) resulted in a significant beta weight.

Table 9. Summary of Multiple Regression Analysis for OCB-I

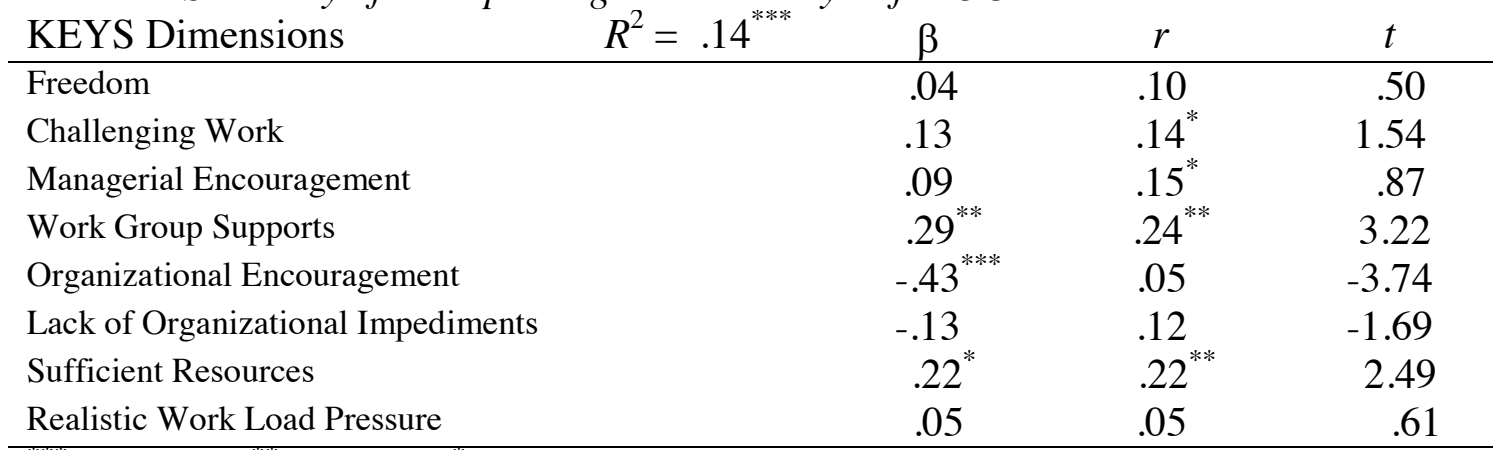

$-p<.001,{ }^{* *}-p<.01,{ }^{*}-p<.05$

This suggests that along with employees perceiving their direct work-teams as being skilled and supportive, their having access to appropriate resources also predicts employee pro-social behaviors targeted at other co-workers. However, the dimension of organizational encouragement displayed a negative relationship with OCB- I, meaning that more organizational encouragement equated with less OCB-I.

\section{Research Questions}

The first research question I asked was which dimensions of organizational climates for creativity and OCB are related. To address this research question, I examined the bivariate correlation matrix including the eight climate for creativity dimensions and the OCB scales (see Table 6). All of the dimensions of climate for creativity were consistently and positively related to sportsmanship - correlations ranged from .17 to .33 . This suggests that employee perceptions of organizational climates that meet all of the eight dimensions of creativity measured in the KEYS are significantly related to increased self-reported sportsmanship behaviors such as not complaining over trivial 
matters, and not focusing on negative aspects of their organizations. Managerial encouragement $(r=.33, p<.01)$ and realistic workload pressure $(r=.30, p<.01)$ demonstrated the strongest relationships, suggesting that encouragement from one's direct manager and having realistic time deadlines are most strongly related to sportsmanship behaviors.

Challenging work $(r=.16, p<.05)$, managerial encouragement $(r=.16, p<.05)$, work group supports $(r=.23, p<.01)$, and sufficient resources $(r=.24, p<.01)$ displayed significant positive relationships with altruism. These results suggest that employee perceptions of having challenging jobs, being supported in their socialexchange relationships (including their managers and co-workers), and having the appropriate resources are related to increased self-reported altruistic behaviors.

The dimensions of challenging work $(r=.23, p<.05)$, managerial encouragement $(r$ $=.15, p<.05)$, and organizational encouragement $(r=.14, p<.05)$, displayed significant positive relationships with civic virtue. These results suggest that challenging jobs and perceived support from both managers and the organization relate to increased selfreported pro-organizational behaviors, such as attending functions or meetings that are not mandated.

Work group supports $(r=.20, p<.01)$ and sufficient resources $(r=.15, p<.05)$ displayed significant positive relationships with courtesy. These results suggest that employee perceptions of being part of highly skilled and supportive work groups, with access to the appropriate resources to do their jobs are related to increased self-reported pro-social behaviors targeted at fellow co-workers. 
Realistic workload pressure only displayed a significant relationship with conscientiousness $(r=-.17, p<.05)$. Interestingly, this relationship is such that higher amounts of extreme pressures and time limits correlated with higher levels of selfreported conscientiousness behaviors (e.g., extreme organizational compliance).

Finally, change-oriented OCB displayed significant relationships with freedom $(r=$ $.21 ; p<.01)$, challenging work $(r=.26 ; p<.01)$, and work group supports $(r=.18 ; p<$ $.05)$. This indicates that employee perceptions of having freedom in their jobs, having jobs with challenging work, and being in highly-skilled and supportive work groups are related to increased self-reported behaviors aimed at suggesting and implementing work improvement ideas and techniques.

Research question 2 asked the potential relationship between the outcome variables (organizational creativity and productivity) and the dimensions of OCB. All of the OCB dimensions were significantly related to productivity ranging from .20 to .27 (see Table 6). While only sportsmanship $(r=.14, p<.05)$, civic virtue $(r=.16, p<.05)$, and change-oriented OCB $(r=.29, p<.01)$, displayed significant relationships to creativity. This suggests that employees perceptions of organizations consisting of climates where a great deal of creativity is called for and where employees that believe that they actually produce creative work, correlated significantly OCB. Such behaviors include not complaining, attending optional organizational meetings, and making and implementing improvements to organizational and job processes. Finally, more of the OCB dimensions were related to productivity than to creativity, with stronger relationships to productivity 
than creativity as well. This result is interesting, but not unexpected, as OCB is essentially a discretionary form of employee productivity.

Research question 3 asked which organizational climates for creativity dimensions account for the most variance in each of the OCB dimensions. To answer this question I performed a series of multiple regression analyses with each OCB subscale mean as a criterion variable and then the eight KEYS climate dimensions as predictor variables for each analysis.

To begin, eight percent of the total variance of conscientiousness was accounted by the dimensions of climate for creativity, $R^{2}=.08, F(8,198)=2.13, p<.05$. Work group supports $(\beta=.20, p<.05)$, organizational encouragement $(\beta=-.30, p=.01)$, and realistic workload pressure $(\beta=-.18, p<.05)$ all displayed uniquely significant relationships with conscientiousness (see Table 10).

Table 10. Summary of Multiple Regression Analysis for Conscientiousness

\begin{tabular}{|c|c|c|c|}
\hline KEYS Dimensions & $R^{2}=.08^{*}$ & $r$ & $t$ \\
\hline Freedom & -.06 & -.07 & -.73 \\
\hline Challenging Work & .11 & .06 & 1.19 \\
\hline Managerial Encouragement & .03 & -.03 & .25 \\
\hline Work Group Supports & $.20^{*}$ & .08 & 2.21 \\
\hline Organizational Encouragement & $-.30^{*}$ & -.09 & -2.51 \\
\hline $\begin{array}{l}\text { Lack of Organizational } \\
\text { Impediments }\end{array}$ & .07 & -.04 & .89 \\
\hline Sufficient Resources & .09 & .00 & .98 \\
\hline Realistic Work Load Pressure & $-.18^{*}$ & $-.17^{*}$ & -2.09 \\
\hline
\end{tabular}

$\stackrel{* * *}{*} p<.001,{ }^{* *}-p<.01,^{*}-p<.05$

This suggests that employee perceptions of support from their work groups related to increased self-reported compliance toward the organization. However, judging from the 
negative beta weights for both organizational encouragement and realistic workload pressure, it appears that more organizational support and less pressure to complete workloads related to increased reports of conscientiousness.

Climate for creativity also accounted for $19 \%$ of the variance in sportsmanship, $R^{2}=$ $.19, F(8,198)=5.76, p<.001$. Managerial encouragement $(\beta=.22, p<.05)$ and realistic workload pressure $(\beta=.22, p<.01)$ displayed significant relationships with sportsmanship (see Table 11). This suggests that employee perceptions of managerial support for creativity and realistic workloads and deadlines relates to increased selfreported sportsmanship behaviors (such as not making trivial complaints or finding fault with the organization).

Table 11. Summary of Multiple Regression Analysis for Sportsmanship

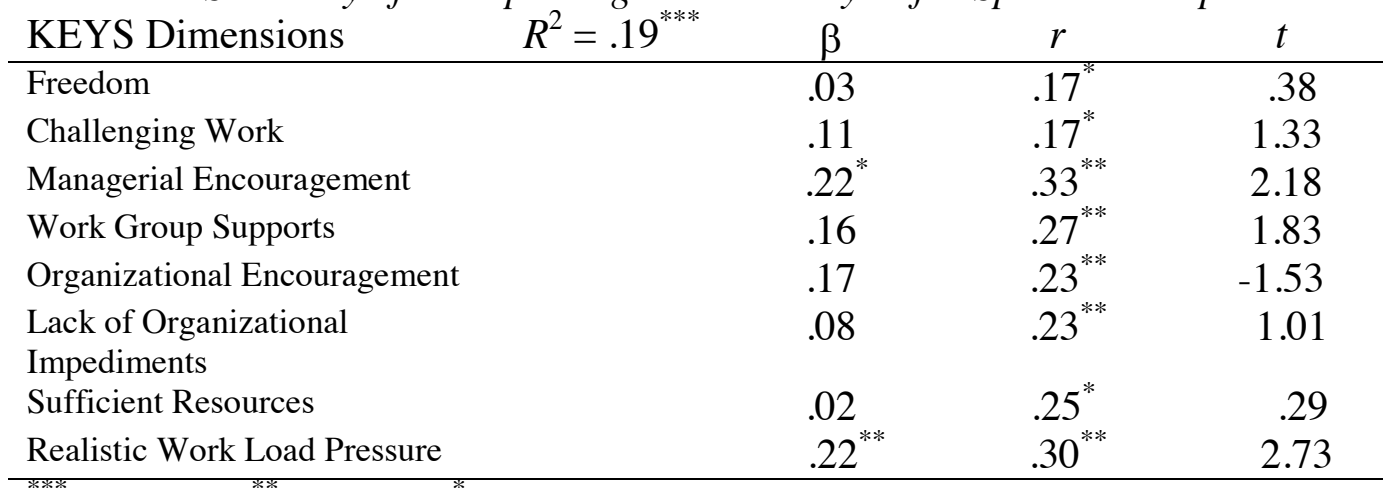

*** $-p<.001,^{* *}-p<.01,^{*}-p<.05$

Nine percent of the variance in civic virtue behaviors was significantly accounted for by the climate for creativity dimensions, $R^{2}=.09, F(8,198)=2.36, p<.05$. Challenging work $(\beta=.17, p<.05)$ and realistic workload pressure $(\beta=-.19, p<.05)$ displayed significant beta weights for this regression, suggesting that employee perceptions including having more challenging work and less realistic workloads are related to 
increased self-reported pro-organizational behaviors (such as attending optional meetings and keeping up with announcements/memos, etc.) (see Table 12).

Table 12. Summary of Multiple Regression Analysis for Civic Virtue

\begin{tabular}{|c|c|c|c|}
\hline KEYS Dimensions & $R^{2}=.09^{*} \quad \beta$ & $r$ & $t$ \\
\hline Freedom & -.08 & .02 & -1.05 \\
\hline Challenging Work & $.17^{*}$ & $.23^{*}$ & 1.98 \\
\hline Managerial Encouragement & .10 & $.15^{*}$ & .92 \\
\hline Work Group Supports & -.01 & .12 & -.12 \\
\hline Organizational Encouragement & -.03 & $.14^{*}$ & -.24 \\
\hline $\begin{array}{l}\text { Lack of Organizational } \\
\text { Impediments }\end{array}$ & .10 & .03 & 1.25 \\
\hline Sufficient Resources & .12 & .14 & 1.32 \\
\hline Realistic Work Load Pressure & $-.19^{*}$ & -.11 & -2.16 \\
\hline
\end{tabular}

${ }^{* * *}-p<.001,^{* *}-p<.01,^{*}-p<.05$

Eleven percent of the variance in courtesy behaviors was significantly accounted for by climate for creativity, $R^{2}=.11, F(8,198)=2.44, p<.01$. Work group supports $(\beta=$ $.27, p<.05)$, organizational encouragement $(\beta=-.41, p=.001)$, and lack of organizational impediments $(\beta=.16, p<.05)$ displayed significant relationships with courtesy (see Table 13). These results show that employees reported increased pro-social behavior toward fellow co-workers when they were part of highly skilled and creatively supportive work groups, perceived less organizational support, and organizational culture that encourages creativity.

Finally, $13 \%$ of the variance of altruism behaviors was significantly accounted for by climate for creativity, $R^{2}=.13, F(8,198)=3.72, p<.001$. Work group supports $(\beta=$ $.25, p<.01)$, organizational encouragement $(\beta=-.37, p<.01)$, and sufficient resources $(\beta=.24, p<.01)$ displayed significant relationships with altruistic behaviors (see Table 14). This result indicates that along with being a part of skilled and diverse work groups 
and perceiving less overall organizational support, employee perceptions of having more resources to do their jobs also related to increased self-reported pro-social behaviors toward fellow co-workers.

Table 13. Summary of Multiple Regression Analysis for Courtesy

\begin{tabular}{|c|c|c|c|}
\hline KEYS Dimensions & $R^{2}=.11^{* *}$ & $r$ & $t$ \\
\hline Freedom & .06 & .09 & .74 \\
\hline Challenging Work & .08 & .09 & .88 \\
\hline Managerial Encouragement & .11 & .11 & 1.06 \\
\hline Work Group Supports & $.27^{* *}$ & $.20^{* *}$ & 2.97 \\
\hline Organizational Encouragement & $-.41^{* *}$ & .01 & -3.51 \\
\hline $\begin{array}{l}\text { Lack of Organizational } \\
\text { Impediments }\end{array}$ & $.16^{*}$ & .13 & 2.07 \\
\hline Sufficient Resources & .15 & $.15^{*}$ & 1.72 \\
\hline Realistic Work Load Pressure & -.10 & .01 & -1.14 \\
\hline
\end{tabular}

Table 14. Summary of Multiple Regression Analysis for Altruism

\begin{tabular}{|c|c|c|c|c|}
\hline KEYS Dimensions & $R^{2}=.13^{* * *}$ & $\beta$ & $r$ & $t$ \\
\hline Freedom & & .01 & .09 & .12 \\
\hline Challenging Work & & .16 & $.16^{*}$ & 1.89 \\
\hline Managerial Encouragement & & .05 & $.16^{*}$ & .48 \\
\hline Work Group Supports & & $.25^{* *}$ & $.23^{* *}$ & 2.76 \\
\hline Organizational Encouragement & & $-.37^{* *}$ & .07 & -3.16 \\
\hline $\begin{array}{l}\text { Lack of Organizational } \\
\text { Impediments }\end{array}$ & & .08 & .10 & 1.04 \\
\hline Sufficient Resources & & $.24^{* *}$ & $.24^{* *}$ & 2.75 \\
\hline Realistic Work Load Pressure & & .00 & .07 & .05 \\
\hline
\end{tabular}

${ }^{* * *}-p<.001,{ }^{* *}-p<.01,{ }^{*}-p<.05$

\section{Discussion}

This study examined the relationship between employee perceptions of how creative the climate was in their organizations and the extent to which they reported engaging in pro-social behaviors targeted at fellow co-workers and the organization as a whole. The review of literature on OCB and organizational climates for creativity in the preceding 
sections clearly present empirical examples and some theoretical arguments of the similarities in various antecedent variables and dimensional characteristics between the two. As of yet, the relationship between the dimensions that comprise OCB and organizational climates for creativity had yet to be examined simultaneously. Results of the present study demonstrate evidence to support such a contention.

Although each of the three hypotheses regarding specific relationships between these constructs was only partially supported, there is some knowledge to be gained from the study. There is definitely an overall indication of some evidence for a link between employee perceptions of organizational climates for creativity employees' self-reported pro-social behaviors targeted at their organizations and fellow co-workers from the results of this study.

More specifically, the first hypothesis that all the dimensions of organizational climates for creativity would predict change-oriented OCBs was partially supported. The dimensions of freedom, challenging work, and work group supports all significantly predicted change-oriented OCB. However, these findings are not consistent with previous findings on change-oriented OCB. Choi, (2007) found a strong vision from top management and organizational encouragement in the form of an innovative climate to be significant predictors for change-oriented OCB.

For the present study, the dimensions that addressed management's vision and organizational support (i.e., managerial and organizational encouragement) were not significant predictors of change-oriented OCB. One possible explanation for these inconsistent findings is that Choi's (2007) study involved employees from one company 
studied for an extended period of time, while the present study surveyed employees across a variety of organizations at one point in time. That is, for a single-company study on change-oriented OCB over some length of time, employees' perceptions of the organizational culture and management's vision appear to take precedence over more proximal factors (e.g., job characteristics, work group supports, or resources).

Additionally, over $30 \%$ of the participants in the current study reported working in their current organizations for less than one year, and thus this portion of the sample may not have had enough time to be exposed to the top management's vision or feel "encouragement" from their organizations. More proximal factors (i.e., variables with a clearer line-of-sight for newer employees) such as freedom, challenging work, and work group supports may be more important when it comes to demonstrating change-oriented OCBs. This may especially be the case when examining short-term employee perceptions across multiple organizations, as in the present study.

The second and third hypotheses regarded the nature of the relationships between the dimensions of climate for creativity and the OCB-I and OCB-O factors. To be sure, it was posited that by looking at the targets of the OCB factors (i.e., the organization or individuals), the climate for creativity dimensions would be better predictors based on their relative emphasis. For example, for Hypothesis 2, I assumed that the climate for creativity dimensions that were derived from the organization (e.g., organizational encouragement, realistic workload pressure, and sufficient resources) would be better predictors for OCB-O than OCB-I. Comparatively, for Hypothesis 3, I predicted that managerial encouragement and work group supports would be better predictors of OCB- 
I, because these climate dimensions assess the perceived quality of employees' socialexchange relationships at work. I presumed, therefore, that these would be strongly related to self-reported employee pro-social behaviors targeted specifically at other coworkers (OCB-I).

There was only partial support for both Hypotheses 2 and 3. Although the climate for creativity dimensions did significantly predict both OCB-O and OCB-I as predicted, there was indeed very little difference regarding which dimensions were more strongly related to either form of OCB. Creative climate accounted for an almost equal amount of variance in both OCB-I and OCB-O dimensions. Both work group supports and organizational encouragement also uniquely accounted for variances in these OCBs. The only difference between OCB-I and OCB-O regarding the multiple regression analyses was that challenging work uniquely accounted for variance in OCB-O, and sufficient resources uniquely accounted for variance in OCB-I.

Taken together, these findings suggest that employee OCB-I and OCB-O behaviors share some fundamental, or essential, relational attributes with regards to certain dimensions of creative organizational climates. However, when employees perceived a sense of having to work hard on challenging tasks and important projects they were more likely to report engaging in pro-organizational behaviors. Comparatively, having access to appropriate resources, including funds, materials, facilities, and information was a better predictor of reported employee pro-social behaviors targeted at other co-workers, such as being more helpful and courteous. However, this finding must be interpreted with caution since it was difficult to 
differentiate OCB into two separate factors in the current study, as the results from the factor analysis suggested that such multi-dimensionality did not exist.

Interestingly, the dimension of organizational encouragement had a negative beta weight for both OCB-I and OCB-O. This may be explained as the result of suppression from one, or several, of the other dimensions of climate for creativity (Tabachnick \& Fidell, 2007). Such a finding occurs in multiple regression analyses when one of the predictor variables is strongly related to one or more of the other predictor variables, but not related to the criterion variable. Organizational encouragement was strongly related to almost the entire array of climate for creativity dimensions, with the exception of realistic workload pressure, but it was not that strongly related to the OCB dimensions. Thus, it seems to be that the dimension of organizational encouragement acted as a suppressor variable in the multiple regression analyses. Therefore, the negative correlation between the dimension of organizational encouragement with any of the OCB dimensions should be interpreted with caution.

Regarding the research questions, the first research question asked which dimensions of climates for creativity were related to OCB. While sportsmanship was the only dimension of OCB to be significantly related to all eight dimensions of climates for creativity, the dimensions of civic virtue, courtesy, altruism, and change-oriented OCB all were significantly related to at least two dimensions of climates for creativity. Interestingly, conscientiousness was only significantly related to one climate for creativity dimension, realistic workload pressure. The more realistic pressure employees perceived for their workloads (e.g., absence of extreme time pressures), the less 
frequently employees reported being conscientious and compliant toward their organizations.

One thought on why this might be, is that the dimension of conscientiousness appears to be more of a static, trait-like variable, with items resembling behaviors that are tied to one's overall personality (e.g., I believe in giving an honest day's work for an honest day's pay). Previous research has also explored the tie between conscientiousness as a personality trait and $\mathrm{OCB}$ as contextual performance (i.e., contributions that sustain an ethos of cooperation and interpersonal supportiveness of the group) (Hattrup, O’Connell, \& Wingate, 1998; LePine \& Van Dyne, 2001; Van Scotter, \& Motowidlo, 1996). Perhaps, this may explain why the situational nature of the climate for creativity dimensions did not have a significant relationship with employee-reported conscientiousness for the most part, but the negative relationship between realistic workload pressure and conscientiousness leaves something to be desired. Such a result suggests that the more employees perceived tight and unrealistic work deadlines, the more compliant they become to their organization's rules and policies, which in itself is a counterintuitive finding.

The dimensions of challenging work and work group supports most frequently correlated significantly with all of the OCB dimensions. Thus, it appears that for the current study, employee perceptions of having to work hard on challenging tasks and important projects, with teams of diversely skilled and supportive work groups who communicate well and are open to ideas, were important variables in predicting employee self-reported pro-social behaviors. 
The climate for creativity dimension that dealt with employee perceptions of having a lack of internal political problems, harsh criticism of new ideas, destructive internal competition, and overemphasis on the status-quo (lack of organizational impediments) was significantly related to sportsmanship. It makes sense that sportsmanship was significantly related to this dimension because such factors most likely lead to antithetical sportsmanship behaviors, but the fact that the other OCB dimensions of conscientiousness, altruism, courtesy, civic-virtue, and change-oriented OCB were not related is interesting. From a general perspective this finding seems somewhat counterintuitive, because lack of organizational impediments is the only climate for creativity dimension that measures a culmination of several negative circumstances. This suggests that the expression of most forms of OCB is resilient to even some negative extremes, such as internal political problems, harsh criticism, or an overemphasis on the status quo, at least for the present study.

Research question 2 asked the nature of the relationships between the eight dimensions of climate for creativity and the six OCB dimensions. To the question of whether or not climates for creativity as a whole predict OCB in the present study, the answer is yes. That is, for each separate dimension of OCB tested, including the two aggregated dimensions of OCB-O and OCB-I, the eight dimensions of climates for creativity accounted for significant amounts of variance in these variables.

Just as sportsmanship was significantly related to all eight dimensions, it was also the OCB dimension with the most variance explained by the climate for creativity dimensions. Only the dimensions of realistic workload pressure and managerial 
encouragement displayed significant beta weights and thus significantly related to sportsmanship however. This finding indicates that the less employees experienced extreme time pressures, unrealistic expectations for productivity, and distractions from creative work, along with having a boss who serves as a good work model with fair goals and confidence in the their work groups, the less likely employees are to complain about trivial work issues, focus on the negative rather than the positive, and find fault with what their organizations are doing. In such a climate it is not likely for employees to find faults with their organizations, so this finding is somewhat to be expected.

Across all of the OCB dimensions, the dimension of work group supports most frequently displayed significant beta weights and thus most consistently significantly related to the OCB dimensions. The dimension of work group supports conceptually addresses a healthy social-exchange environment for promoting creativity, such that the employees believe that they work in diversely skilled groups, where people communicate well, are open to new ideas, constructively challenge each other's work, trust in and help each other, and feel committed to the work they are doing. As would be expected, this dimension significantly predicted participants reporting OCB-I but also for conscientiousness and change-oriented OCB.

Thus, when employees perceive the presence of a healthy social-exchange environment for creativity, they are not only more likely to engage in pro-social behaviors toward other co-workers (e.g., by trying to prevent problems before they arise, or helping others even if not required to do so), but they are also more likely to comply with the organizational rules and to be efficient workers, while also suggesting and/or 
implementing new ideas to improve their own work. Finally, this finding highlights the previously mentioned literature regarding the possibility of trait activation theory and OCB, i.e., "where interactions in which high quality social exchange relationships weaken the positive effects of personality traits on performance" (Tett \& Burnett, 2003, p.502). As it was demonstrated here that the quality of the social exchange relationships employees experienced in their work environments contributed significantly to their reports of conscientious behaviors (Kamdar \& Van Dyne, 2007).

The final research question addressed the nature of the relationships between the KEYS criterion variables - creativity and productivity - and OCB. All of the OCB dimensions were significantly and positively related to productivity, with sportsmanship and civic virtue having the strongest relationships. This indicates that the more employees reported perceiving their organizations and work-units as efficient, effective, and productive, the more they reported pro-organizational behaviors. Since OCB can certainly conceptualized as a form of employee performance, this finding makes sense. Sportsmanship, civic virtue, and change-oriented OCB were significantly correlated with the creativity criterion variable, such that employees perceiving their organizations and/or work-units as being creative, i.e., where a great deal of creativity is called for, and where the people working with them believe that they actually produce creative work, correlated significantly with participant reports of these three OCB dimensions.

These findings are consistent with Schepers and Van Den Berg (2007) where the social factors of work-environment creativity (similar to climate for creativity) facilitate 
pro-social behaviors such as employee knowledge sharing. The present study builds slightly on this topic, such that organizations which have employees who perceive a climate for creativity are not only related to employee pro-social behaviors such as knowledge sharing (OCB-I), but also significantly and positively related to proorganizational behaviors, such as not complaining about trivial matters and keeping current with organizational information and/or functions.

Furthermore, change-oriented OCB was the OCB dimension most strongly related to the KEYS criterion variable of creativity. This finding indicates that employee perceptions of creative output and employee behaviors directed at improving employee and organizational efficiency in the forms of coming up with new ideas for work methods, and suggesting changes to unproductive organizational rules or policies are strongly related to one another.

\section{Strengths and Limitations of the Study}

There are several strengths of the study. First, the current study involved participants who were employed in several different organizations for the intention of generalizing the results across multiple demographic variables (i.e., employees’ employment status, their time working with their organizations, the size of their organizations, and the industry/sector of their organizations). Because this study looked at such a diverse group of people and organizations, the results here might be ecologically valid, and offer insight into generalizing the nature of the relationships between the constructs of interest. 
Second, this study builds on the literature of OCB and organizational climates for creativity, and bridges the gap between these constructs. In the preceding sections it was clearly presented that there are empirical examples and theoretical arguments for the similarities in various antecedent variables and dimensional characteristics between OCB and organizational climates for creativity. However, as of yet, the current literature has not examined whether any relationship exists between the dimensions that comprise both constructs of interest. The results of the present study demonstrate evidence to support this contention, while also bringing further detail to the nature of the relationships between climates for creativity and OCB.

Despite the strengths of the study, the results from this present study should also be considered along with several limitations that may have impacted the research. First, this study consisted of participants responding to a single survey to assess multiple constructs consisting of multiple dimensions. Using self-ratings for both predictor and criterion variables is often discouraged because of concerns regarding common method bias, or, the belief that research methods used contribute some variance to the relationships being tested (Spector, 2006). Accordingly, the obtained correlations might have been somewhat more inflated than they actually are.

Additionally, the use of self-ratings may be prone to social desirability bias, for example, especially the inflation of self-ratings of OCB, so the collection of data on such voluntary employee behaviors may be more reliable using conservative practices such as supervisor or co-worker ratings. Dalal's (2005) meta-analysis of the relationship between OCB and counterproductive work behavior (CWB) investigated the moderating effects of 
rating sources (supervisor versus self-report) on this relationship. The strength of the relationship between $\mathrm{OCB}$ and $\mathrm{CWB}$ differed as a function of the source of the ratings, such that supervisor ratings yielded a much stronger relationship than did self-report ratings (Dalal, 2005). O'Brien and Allen (2008) also measured rating source in relation to several correlates of OCB and CWB. Their patterns of findings were more similar than dissimilar across rating source (supervisor versus self-report), however, the magnitude of the observed relationships varied greatly such that self-report ratings were inflated compared to supervisor ratings (O’Brien \& Allen, 2008). Thus, for the present study, the confounding effects of social desirability responding and/or common method bias may have affected the results, and thus all results should be interpreted cautiously. Additionally, the characteristics of the current sample might have posed some limitations. I was able to screen participants and control for those with less than six months tenure at their organizations with the hopes of tapping into the perceptions of employees who were not necessarily new-hires. Despite setting this filter the sample still consisted of $33 \%$ of employees working between six months and one year. The possibility that six months is still not an adequate amount of time for employees to assess an accurate perception of their organizational climate might be a factor that limited the generalizability of these results, and may be a possible area for future research to investigate. Furthermore, most of the participants had entry-level positions. Consequently, another limitation of this study is that the participants might not have been able to perceive whether or not they had work group supports or organizational 
encouragement, due to their short tenure. Results may have been different from those who have had higher-level jobs, or longer tenure with their organizations.

\section{Suggestions For Future Research}

As mentioned earlier, one possible consideration for future research aimed at exploring organizational climates for creativity and OCB is to investigate how these perceptions change over time, or when employees genuinely perceive their organizational climates accurately. This might be addressed by tracking a sample over time using a longitudinal design. Also mentioned earlier, future research in this area can be more rigorously designed so as to include a third-party rating source for employee OCB (i.e., supervisors or co-workers).

Finally, future research might also expand on the current results by including personality measures as well. The current research was limited in scope by not including personality variables, especially as previous research has shown links between personality and creativity. It might be interesting to include attributes connected with the generation of ideas, aspects of problem solving, and the drive to implement ideas in future research (Barron \& Harrington, 1981). Other personality factors related to creativity, such as openness to new experiences, non-conventionality, self-confidence, drive, ambition, dominance, and impulsiveness would also prove interesting to see incorporated into future research (Feist, 1999; Helson, 1999).

\section{Implications and Conclusion}

Some of the key findings from this research might apply to a broader group of people. Theoretically, this study provides support for my argument made earlier 
regarding Maslow's (1954) theory of self-actualization as a possible model for how creative climates may relate to OCB. When employees report having the appropriate combination of challenging work with the required resources needed to perform their own work, they are more inclined not only to help their co-workers, but also comply with the organizational rules that are in place and not focus on negative aspects within the organization. Furthermore, they might view the fact of being employed by an organization with a creative climate in such a positive light that they feel the need to reciprocate in the form of OCBs toward both the organization and fellow co-workers.

Other implications might derive from the finding that creative climates are moderately related to employee reports of sportsmanship behaviors. Specifically, employee perceptions of the level and diversity of skills, open channels of communication, high levels of trust, and commitment in their work groups is a set of variables that consistently demonstrated a significant relationship with pro-social behaviors directed at their co-workers and their organizations. Accordingly, top management could benefit from implementing measures to address these simple areas as core values in its organizations. According to the present study, organizations may benefit from implementing such strategies by bolstering employees to become more inclined to demonstrate sportsmanship behaviors, which create bountiful outcomes for the organization and its employees (Podsakoff et al., 2009).

Additionally, practical implications might be made from the finding that employee perception of the creativity and productivity of their organizations was strongly related to their own self-reported change-oriented OCBs. This finding is relevant to 
organizations that are in need of constantly maintaining a strategic advantage by assessing the future. Such organizations cannot afford to hold employees by their hands in the non-discretionary details of their jobs, and can benefit greatly from employees who take initiative to both suggest and implement improvements in their daily tasks and in the broader organizational scheme such as policies and procedures. These employees' OCBs are key for organizations that need to adapt to change.

One such industry that can benefit greatly from using this type of information in the planning and design of climate strategies is the technology industry. Technology is growing exponentially, and there is no time to waste for such organizations in designing and implementing a creative climate strategy. Further research investigating the dynamics of organizational climates for creativity and OCB is required to gain a more complete understanding of the two constructs. However, the benefits as gleaned through this present study show that, even if by creating and instilling a climate for creativity, an organization may not achieve some lofty goal of innovating the "next big thing" in the short run, it is still possible that employees might exert discretionary, contextual, performance behaviors in the form of OCBs; pro-social behaviors directed not only toward their fellow co-workers, but also toward the organization as a whole.

Moving forward, it seems that there are additional benefits for organizations providing the climate and culture to encourage creativity, particularly if agility and adaptability to change is a constant necessity. However this application does not have to stop there. As demonstrated in the present study, creative organizational climates 
inherently consist of dimensions that lead to other successful outcomes, both organizationally and for individual employees.

Staffing work groups that are diversely skilled and supportive of the creative process, and designing jobs that are challenging and important are two dimensions that most consistently related to several of the OCB dimensions in the present study, and it may be that they are important for a variety of other outcomes as well.

As employees perceive their organizational climates in such a positive light - from having healthy social-relational exchanges between their co-workers, and intrinsically rewarding jobs, they respond with pro-social and pro-organizational behaviors. This knowledge seems only to be the tip of the iceberg for understanding how organizational climates support such discretionary behaviors, and much more research is needed to fully understand how they create the breeding ground for productivity and creativity. However, once that information is uncovered, it may be useful for increasing organizational performance and employee cooperation in these troubling economic times. 


\section{References}

Alge, B. J., Ballinger, G. A., Tangirala, S., \& Oakley, J. L. (2006). Information privacy in organizations: Empowering creative and extra-role performance. Journal of Applied Psychology, 91(1), 221.

Amabile, T. M. (1988). A model of creativity and innovation in organizations. In B. M. Stew \& L. L. Cummings (Eds.), Research in organizational behavior (pp. 123167). Greenwhich, CT: JAI.

Amabile, T. M. (1996). Creativity in context: Update to 'the social psychology of creativity.'. Boulder, CO US: Westview Press.

Amabile, T. M., \& Conti, R. (1997). Environmental determinants of work motivation, creativity, and innovation: The case of R\&D downsizing. In R. Garud, P. R. Nayyar, Z. B. Shapira, R. Garud, P. R. Nayyar \& Z. B. Shapira (Eds.), Technological innovation: Oversights and foresights. (pp. 111-125). New York, NY US: Cambridge University Press.

Amabile, T. M., Conti, R., Coon, H., \& Lazenby, J. (1996). Assessing the work environment for creativity. Academy of Management Journal, 39(5), 1154-1184.

Amabile, T. M., Schatzel, E. A., Moneta, G. B., \& Kramer, S. J. (2004). Leader behaviors and the work environment for creativity: Perceived leader support. Leadership Quarterly, 15, 5-32.

Atwater, L., \& Carmeli, A. (2009). Leader-member exchange, feelings of energy, and involvement in creative work. The Leadership Quarterly, 20(3), 264-275.

Baas, M., De Dreu, Carsten K. W., \& Nijstad, B. A. (2008). A meta-analysis of 25 years of mood-creativity research: Hedonic tone, activation, or regulatory focus? Psychological Bulletin,134(6), 779-806.

Barron, F., \& Harrington, D. M. (1981). Creativity, intelligence, and personality. Annual Review of Psychology, 32, 439-476.

Bateman, T. S., \& Organ, D. W. (1983). Job satisfaction and the good soldier: The relationship between affect and employee 'citizenship.' Academy of Management Journal, 26(4), 587-595.

Bettencourt, L. A. (2004). Change-oriented organizational citizenship behaviors: The direct and moderating influence of goal orientation. Journal of Retailing, 80, 165180 . 
Borghini, S. (2005). Organizational creativity: Breaking equilibrium and order to innovate. Journal of Knowledge Management, 9(4), 19-33.

Borman, W. C., Penner, L. A., Allen, T. D., \& Motowidlo, S. J. (2001). Personality predictors of citizenship performance. International Journal of Selection and Assessment, 9(1), 52-69.

Choi, J. N. (2007). Change-oriented organizational citizenship behavior: Effects of work environment characteristics and intervening psychological processes. Journal of Organizational Behavior, 28(4), 467-484.

Csikszentmihalyi, M. (1997). Creativity: Flow and the psychology of discovery and invention. New York, NY US: HarperCollins Publishers.

Dalal, R. S. (2005). A meta-analysis of the relationship between organizational citizenship behavior and counterproductive work behavior. Journal of Applied Psychology, 90, 1241-1255.

Dawkins, R. (2006). The selfish gene (30th anniversary edition). New York, NY US: Oxford University Press.

Dunn, W. S., Mount, M. K., Barrick, M. R., \& Ones, D. S. (1995). Relative importance of personality and general mental ability in managers' judgments of applicant qualifications. Journal of Applied Psychology, 80(4), 500-509.

Eisenberger, R., Huntington, R., Hutchison, S., \& Sowa, D. (1986). Perceived organizational support. Journal of Applied Psychology, 71(3), 500-507.

Fehr, E. \& Fischbacher, U. (2003). The nature of human altruism. Nature, 425(6090), 785-792.

Feist, G. J. (1999). The influence of personality on artistic and scientific creativity. In R. J. Sternberg, \& R. J. Sternberg (Eds.), Handbook of creativity. (pp. 273-296). New York, NY US: Cambridge University Press.

Feist, G. J. (2006). The psychology of science and the origins of the scientific mind. New Haven, CT US: Yale University Press.

Guilford, J. P. (1950). Creativity. American Psychologist, 5(9), 444-454.

Hattrup, K., O'Connell, M. S., \& Wingate, P. H. (1998). Prediction of multidimensional criteria: Distinguishing task and contextual performance. Human Performance, 11(4), 305-319. 
Helson, R. (1999). A longitudinal study of creative personality in women. Creativity Research Journal, 12(2), 89-101.

Hui, C., Lam, S. S. K., \& Law, K. K. S. (2000). Instrumental values of organizational citizenship behavior for promotion: A field quasi-experiment. Journal of Applied Psychology, 85(5), 822-828.

Hunter, S. T., Bedell, K. E., \& Mumford, M. D. (2007). Climate for creativity: A quantitative review. Creativity Research Journal, 19(1), 69-90.

Isen, A. M., \& Daubman, K. A. (1984). The influence of affect on categorization. Journal of Personality and Social Psychology, 47(6), 1206-1217.

Johnson, S. (2010). Where good ideas come from: The natural history of innovation. New York, NY US: Penguin Group.

Kanter, R. M. (1983). The change matters: Innovation for productivity in the American corporation. New York: Simon \& Schuster.

Kimberly, J. R. (1981). Managerial innovation. In P.C. Nystrom \& W. H. Starbucks (Eds.), Handbook of organizational design. Oxford, UK: Oxford University Press.

Konovsky, M. A., \& Organ, D. W. (1996). Dispositional and contextual determinants of organizational citizenship behavior. Journal of Organizational Behavior, 17(3), 253266.

Konovsky, M. A., \& Pugh, S. D. (1994). Citizenship behavior and social exchange. Academy of Management Journal, 37(3), 656-669.

LePine, J. A., \& Van Dyne, L. (2001). Voice and cooperative behavior as contrasting forms of contextual performance: Evidence of differential relationships with big five personality characteristics and cognitive ability. Journal of Applied Psychology, 86(2), 326-336.

Martinsen, Ø., \& Kaufmann, G. (1991). Effect of imagery, strategy and individual differences in solving insight problems. Scandinavian Journal of Educational Research, 35(1), 69-76.

Maslow, A. H. (1954). Motivation and personality. Oxford England: Harpers.

Mathisen, G. E., \& Einarsen, S. (2004). A review of instruments assessing creative and innovative environments within organizations. Creativity Research Journal, 16(1), 119-140. 
McLean, L. D. (2005). Organizational culture's influence on creativity and innovation: A review of the literature and implications for human resource development. Advances in Developing Human Resources, 7(2), 226-246.

Meyer, J. P., \& Allen, N. J. (1997). Commitment in the workplace: Theory, research, and application. Thousand Oaks, CA US: Sage Publications, Inc.

Miles, D. E., Borman, W. E., Spector, P. E., \& Fox, S. (2002). Building an integrative model of extra role work behaviors: A comparison of counterproductive work behavior with organizational citizenship behavior. International Journal of Selection and Assessment, 10(1), 51-57.

Moneta, G. B., \& Csikszentmihalyi, M. (1996). The effect of perceived challenges and skills on the quality of subjective experience. Journal of Personality, 64(2), 275-310.

Moorman, R. H. (1991). Relationship between organizational justice and organizational citizenship behaviors: Do fairness perceptions influence employee citizenship? Journal of Applied Psychology, 76(6), 845-855.

Moorman, R. H., Niehoff, B. P., \& Organ, D. W . (1993). Treating employees fairly and organizational citizenship behavior: Sorting the effects of job satisfaction, organizational commitment, and procedural justice. Employee Responsibilities and Rights Journal, 6(3), 209-225.

Motowidlo, S. J., \& Van Scotter, J. R. (1994). Evidence that task performance should be distinguished from contextual performance. Journal of Applied Psychology, 79(4), 475-480.

Niehoff, B. P., \& Moorman, R. H. (1993). Justice as a mediator of the relationship between methods of monitoring and organizational citizenship behavior. Academy of Management Journal, 36(3), 527-556.

O’Brien, K. E., \& Allen, T. D. (2008). The relative importance of correlates of organizational citizenship behavior and counterproductive work behavior using multiple sources of data. Human Performance, 21, 62-88.

Organ, D. W. (1988). Organizational citizenship behavior: The good soldier syndrome. Lexington, MA England: Lexington Books/D. C. Heath and Com.

Organ, D. W. (1997). Organizational citizenship behavior: It's construct clean-up time. Human Performance, 10(2), 85-97. 
Organ, D. W., Podsakoff, P. M., \& MacKenzie, S. B. (2006). Organizational citizenship behavior: Its nature, antecedents, and consequences. Thousand Oaks, CA: Sage Publications Inc.

Organ, D. W., \& Ryan, K. (1995). A meta-analytic review of attitudinal and dispositional predictors of organizational citizenship behavior. Personnel Psychology, 48(4), 775802 .

Piccolo, R. F., \& Colquitt, J. A. (2006). Transformational leadership and job behaviors: The mediating role of core job characteristics. Academy of Management Journal, 49(2), 327-340.

Pillai, R., Schriesheim, C. A., \& Williams, E. S. (1999). Fairness perceptions and trust as mediators for transformational and transactional leadership: A two-sample study. Journal of Management, 25(6), 897-933.

Podsakoff, N. P., Whiting, S. W., Podsakoff, P. M., \& Blume, B. D. (2009). Individualand organizational-level consequences of organizational citizenship behaviors: A meta-analysis. Journal of Applied Psychology, 94(1), 122-141.

Podsakoff, P. M., MacKenzie, S. B., \& Bommer, W. H. (1996). Transformational leader behaviors and substitutes for leadership as determinants of employee satisfaction, commitment, trust, and organizational citizenship behaviors. Journal of Management, 22(2), 259-298.

Podsakoff, P. M., MacKenzie, S. B., Moorman, R. H., \& Fetter, R. (1990). Transformational leader behaviors and their effects on followers' trust in leader, satisfaction, and organizational citizenship behaviors. The Leadership Quarterly, l(2), 107-142.

Podsakoff, P. M., MacKenzie, S. B., Paine, J. B., \& Bachrach, D. G. (2000). Organizational citizenship behaviors: A critical review of the theoretical and empirical literature and suggestions for future research. Journal of Management, 26(3), 513-563.

Schepers, P., \& van, d. B. (2007). Social factors of work-environment creativity. Journal of Business and Psychology, 21(3), 407-428.

Scott, S. G., \& Bruce, R. A. (1994). Determinants of innovative behavior: A path model of individual innovation in the workplace. Academy of Management Journal, 37(3), 580-607. 
Shalley, C. E., Gilson, L. L., \& Blum, T. C. (2000). Matching creativity requirements and the work environment: Effects on satisfaction and intentions to leave. Academy of Management Journal, 43(2), 215-223.

Smith, C. A., Organ, D. W., \& Near, J. P. (1983). Organizational citizenship behavior: Its nature and antecedents. Journal of Applied Psychology, 68(4), 653-663.

Spector, P. (2006). Method variance in organizational research: Truth or urban legend? Organizational Research Methods, 9, 221-232.

Sternburg, R. J., \& Lubart, T. I. (1999). The concept of creativity: Prospects and paradigms. In R. J. Sternburg (Ed.), Handbook of creativity (pp.3-15). Cambridge, UK: Cambridge University Press.

Tabachnick, B. G. \& Fidell, L. S. (2007). Using Multivariate Statistics (5th ed). Boston: Pearson.

Tett, R. P., \& Burnett, D. D. (2003). A personality trait-based interactionist model of job performance. Journal of Applied Psychology, 88, 500 -517.

Van de Ven, A. H., \& Angle, H. L. (1989). An introduction to the Minnesota innovation research program. In A. H. Van de Ven, H. L. Angle, \& M. S. Poole (Eds.), Research on the management of innovation (pp. 3-30). New York: Harper \& Row.

Van Scotter, J. R., \& Motowidlo, S. J. (1996). Interpersonal facilitation and job dedication as separate facets of contextual performance. Journal of Applied Psychology, 81(5), 525-531.

Williams, L. J., \& Anderson, S. E. (1991). Job satisfaction and organizational commitment as predictors of organizational citizenship and in-role behaviors. Journal of Management, 17(3), 601-617.

Yen, H. R., Li, E. Y., \& Niehoff, B. P. (2008). Do organizational citizenship behaviors lead to information system success? Testing the mediation effects of integration climate and project management. Information \& Management, 45, 394-402. 
